\title{
An Analysis of Social Justice Compatibility with Development in Islamic Reflections
}

Ali Larijani ${ }^{1}$ Assistant Professor, Department of Philosophy, Faculty of Literatures and Humanities, University of Tehran, Tehran, Iran.
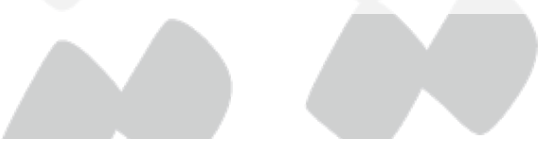

\begin{abstract}
This study attempts to extract the related material regarding social justice theory from religious texts and Islamic elites' reflections. The concern of a great number of philosophers and economists regarding social justice is that imperfect accounts of the social justice concept have obstructed the growth and development of societies. In particular, those that believe in market economy theory try to decelerate development by providing specific interpretations of the social justice phenomenon. But in practice, the reason lies in associating the social justice concept with populist intentions and providing imperfect interpretations of the so-called concept. Based on inherent rights and Islamic texts, this paper aims to show that social justice not only facilitates growth and development but it also motivates competition in various political, cultural, economic and academic arenas.
\end{abstract}

Keywords: Social Justice, Individual Inherent Rights, Development, Islamic Reflection, Freedom. 


\section{مقدمه}

در نظريههاى فيلسوفان سياست و اقتصاددانان، بلويزه آنان كه تاملاتى در فلسفه اقتصاد دارند، در بحث عدالت اجتماعى همواره دلمشغولىهايى نسبت به توسعه و نحوه رشد دارند، مانند اين كه

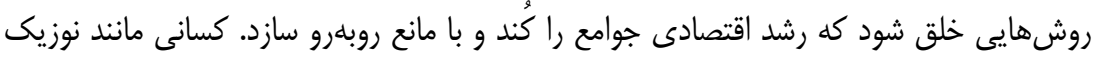

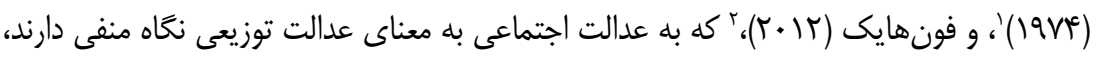

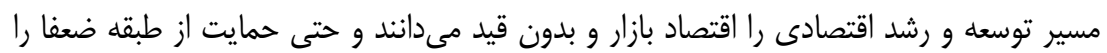
نيز از آن جهت مىيذيرند كه به بهبود فضاى سياسى و تحمل يذيرى مدد مىرساند، و در نهايت به به

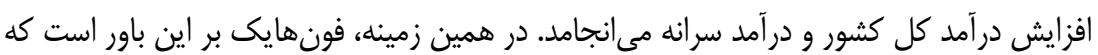
عدالت اجتماعى "كليشهاى ميانتهى" و "سرابگُونه" و از نظر فكرى و نظرى مايه رسوايى است

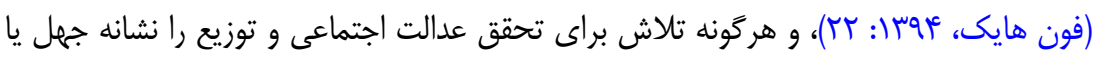

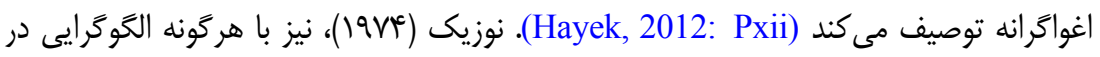
عدالت توزيعى مخالف است. او دولت مشروع را دولت حداقلى مى داند كه وظيفه اصلى آن، تنها تامين حقوق و آزادىهاى اساسى و تضمين رقابت است. وى نظريه تاريخى عدالت بـ را جايخزين

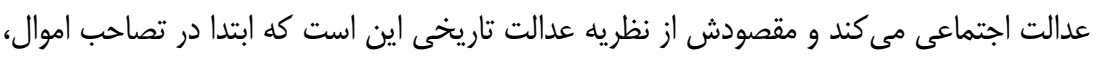

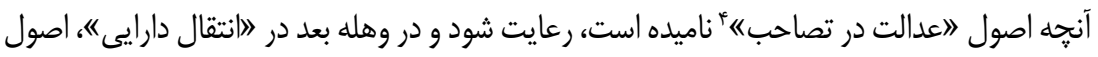
آن مراعات شود و در نهايت 》اكتسابهاى غيرعادلانه《 تصحيح شود. او هيج قيد ديخرى را براى عدالت، حتى اقدامهايى مانند آنجه دولت رفاهٌ انجام مى دهد، نمى يذيرد (Nozick, 1974: 150). برخى اقتصاددانان ايرانى نيز اين نخرانى را دارند كه در يس بحثهاى عدالت اجتماعى، سوداهاى ديخرى وجود داشته باشد كه سرانجام به رشد اقتصادى كشور لطمه وارد كند (نيلى و همكاران، ع (جسا). دغدغه اصلى اين گروه بيشتر از آن جهت است كه اصل رقابت در اقتصاد، كه عامل رشد كشور يا جوامع است، به دليل مداخلههاى دولت از حيز انتفاع بيافتد.

\section{Nozick}

2. Hayek

3. Historical Theory of Justice

4. The Principle of Justice in Acquisition

5. Welfare State 


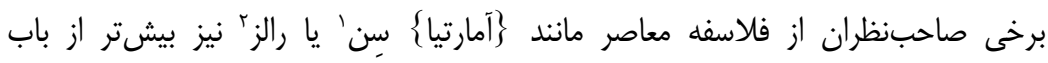

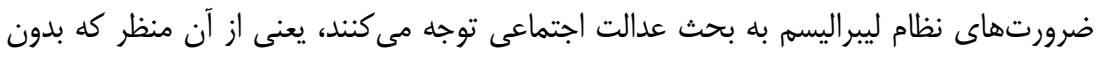

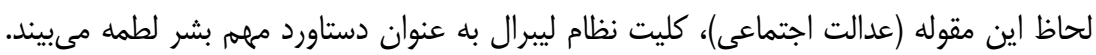

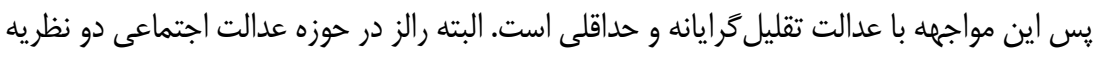

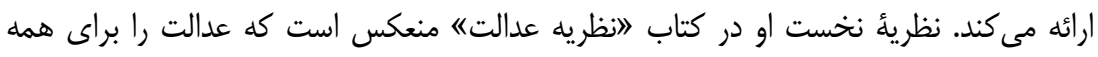

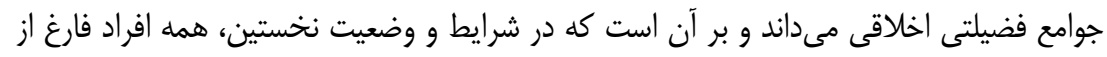

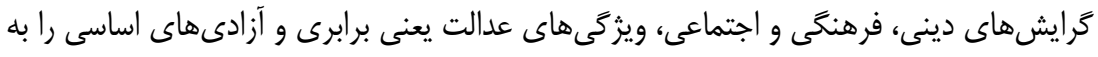

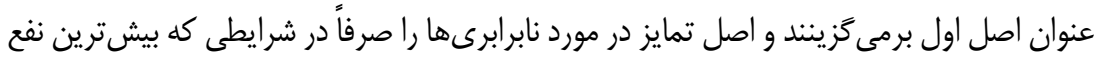

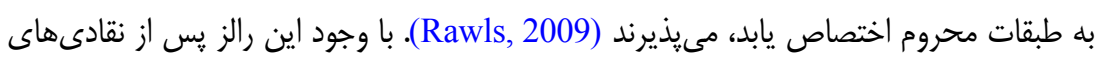

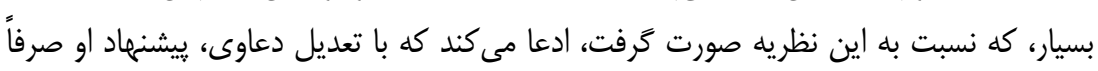

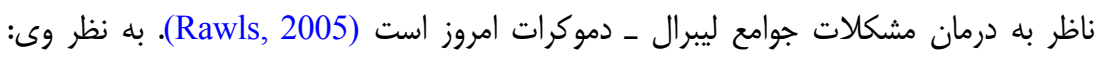

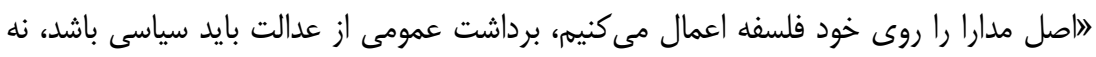

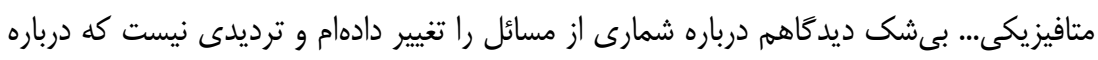

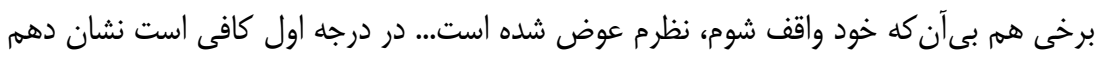

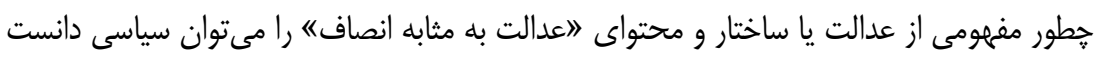

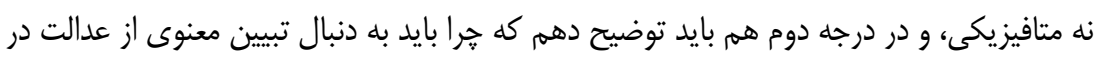

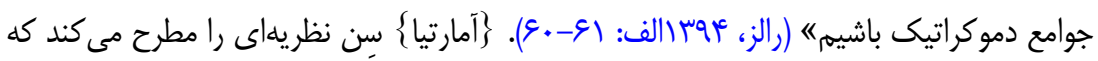

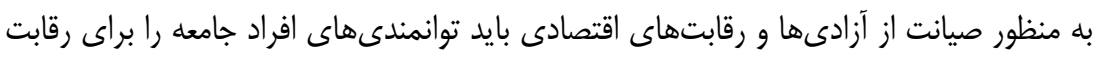

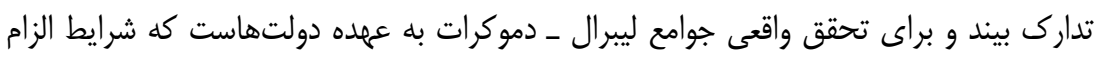

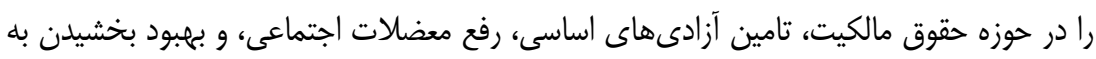

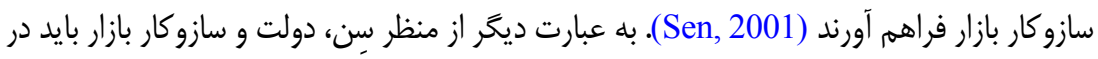

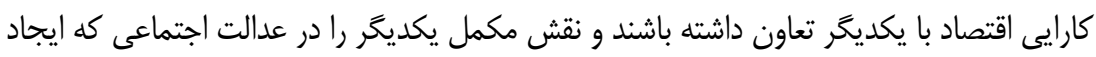

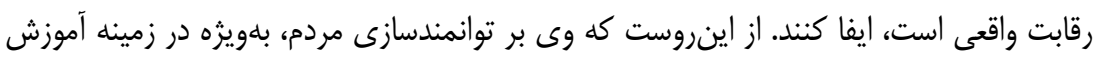

و بهداشت، تمركز مى ايابد (Sen, 2001).

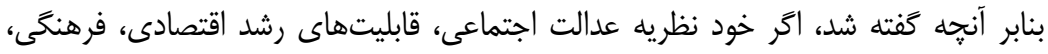

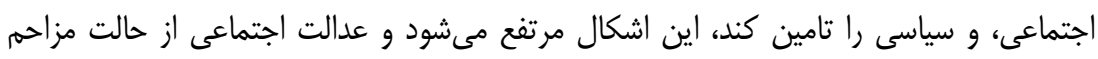

1. Sen

2. Rawls 
به عامل مولد رشد تغيير جايخاه مىيابد. حال بايد نشان داده شود در نكاه اسلامى، اين نامزاحم

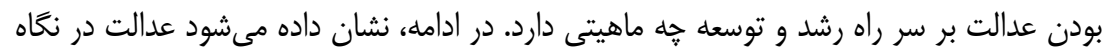

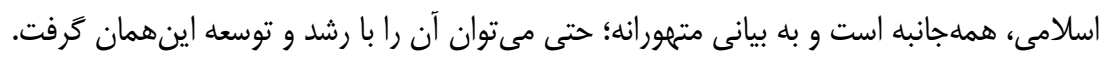

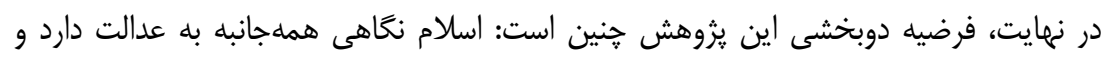

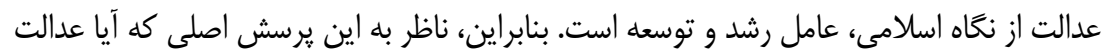

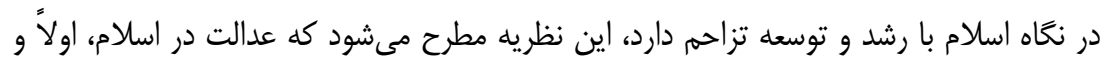

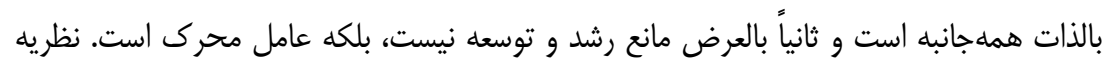

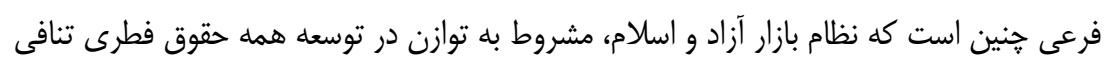

\section{مبانى نظرى ثيزوهش}

اكر امورى مانند آزادى حدبردار هستند، عدالت مفهومى ناحدبردار است. در حقيقت، آزادي

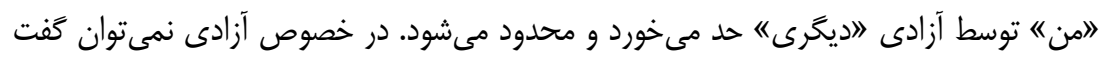

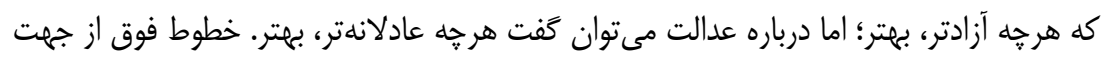

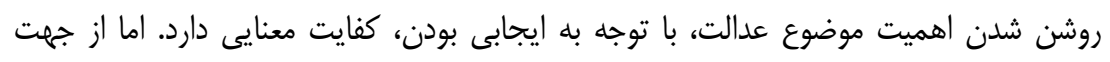

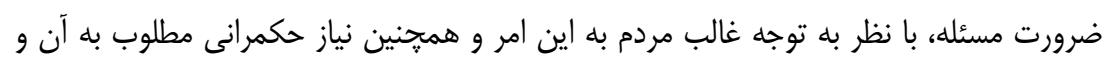

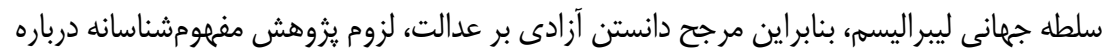
عدالت را فرارو مىنهد.

\section{مبانى فكرى عدالت اجتماعى}

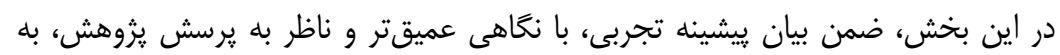

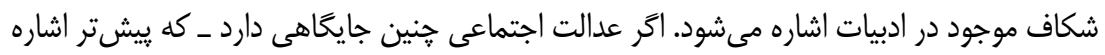

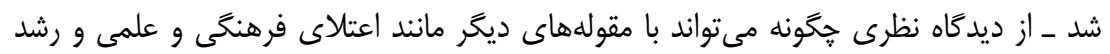

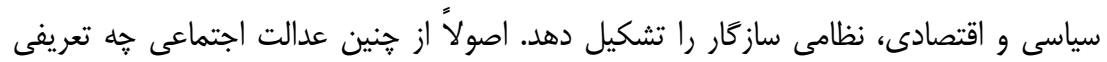

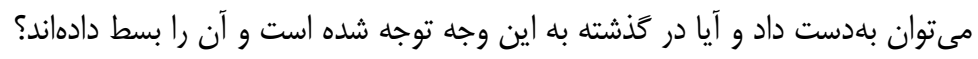

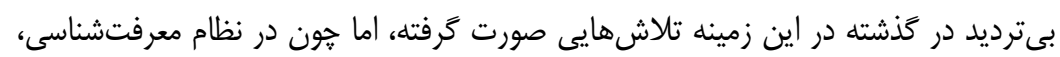

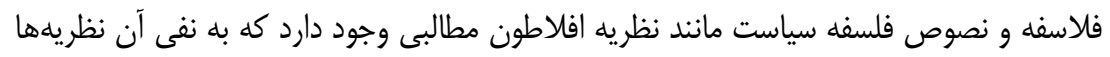

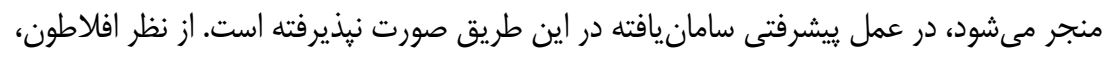


ركن سياست و بالاترين فضيلت، عدالت است و جامعه آرمانى جهار ويزگى دارد: حكمت، شجاعت،

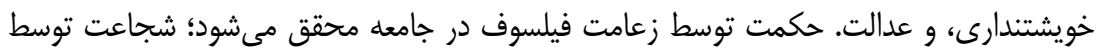
پإساران و نظاميان كه به شيوه خاص تربيت مىشوند، تحقق مىيابد؛ مقصود از خويشتندارى، هماهنكى و انضباط همه بخشهاى حكومت است؛ و سرانجام، عدالت در اين ساختار معنا يبيدا

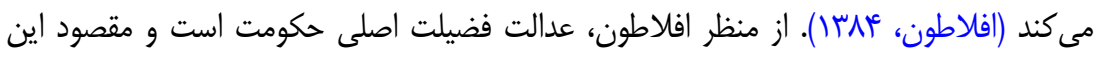

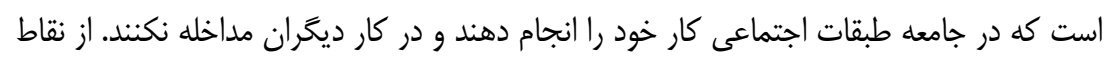

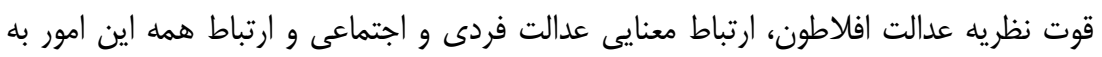
》امثال خير" است، اما در همين فلسفه سياست، انسانها برابر نيستند. فلاسفه در رتبه نخست،

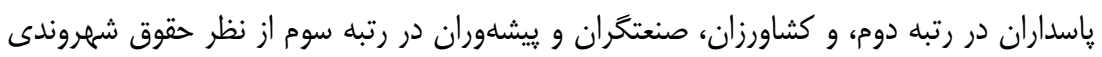

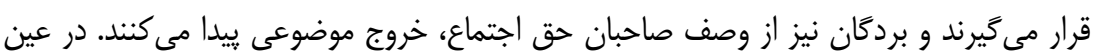

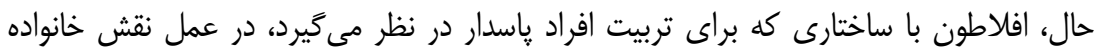

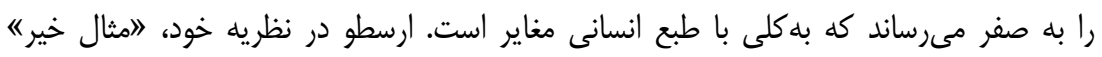

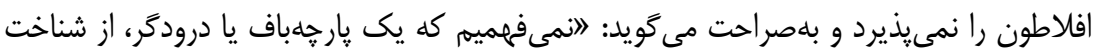

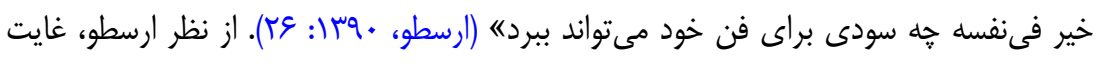

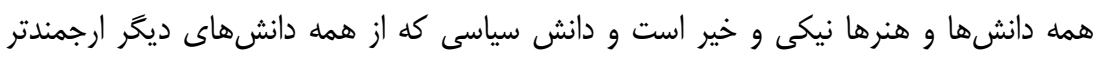

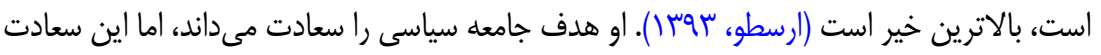

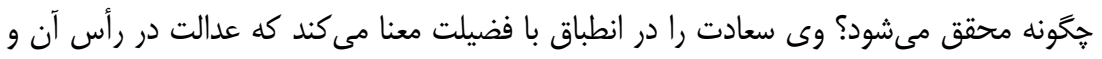

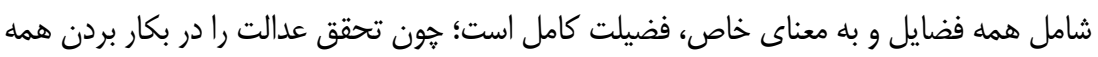

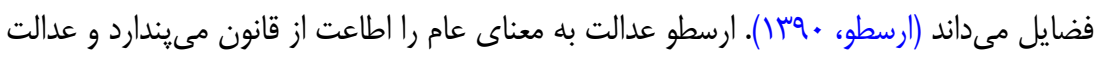

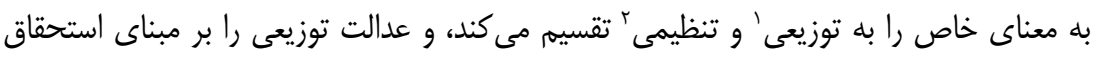

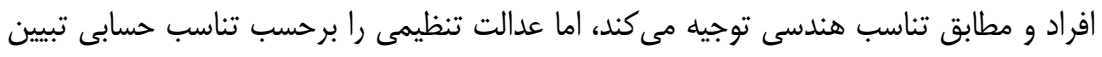

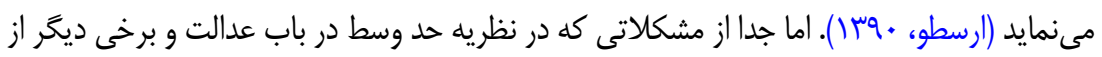

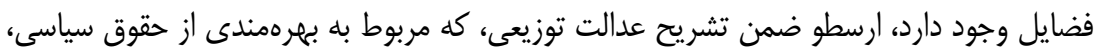

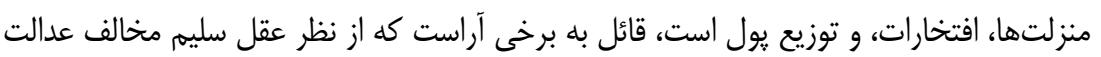

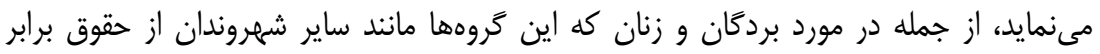

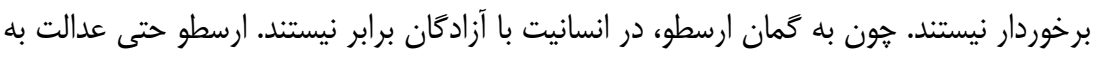

1. Distribution

2. Retribution 
معناى تناسب هندسى را براى عدالت يدر نسبت به فرزندان و عدالت خواجه نسبت به برده خويش

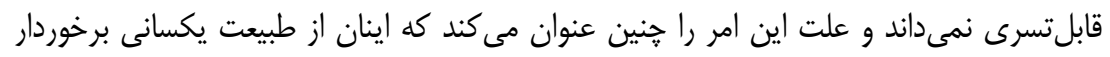

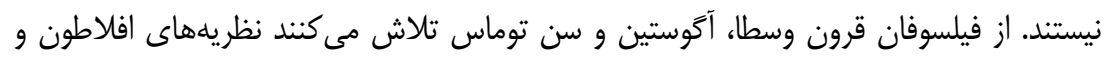

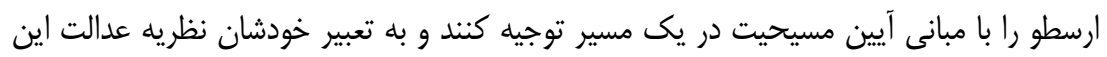
فلاسفه را در درون مسيحيت استعلا مىبخشند. آكوستين در شهر خدا، عدالت واقعى رادر در نظمه

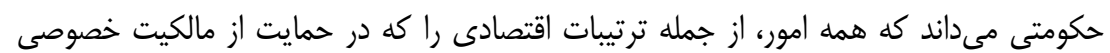

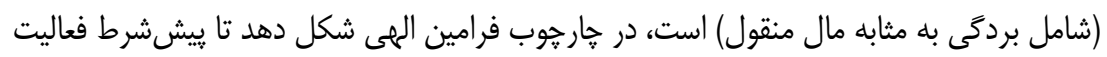

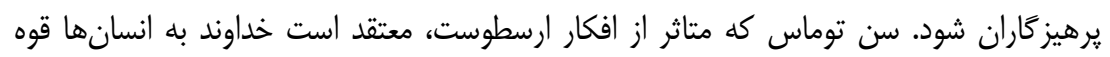

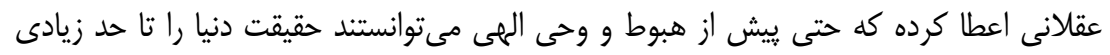

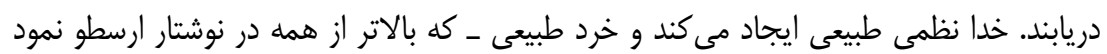

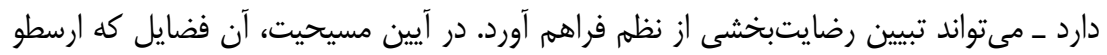

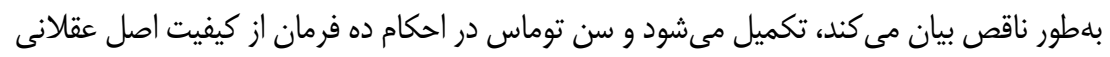

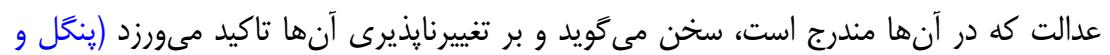

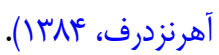

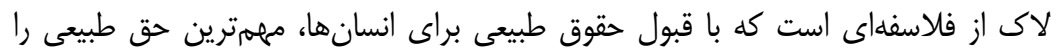
آزادى و مالكيت مىداند (Locke, 1967). حكومت عادلانه در نظر او حكومتى است كه اين دو

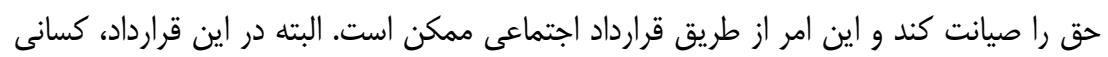

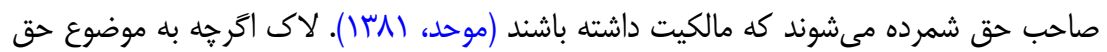

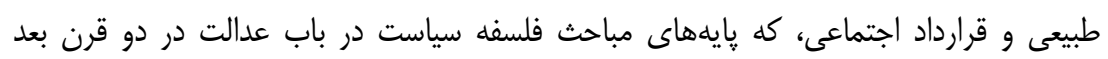

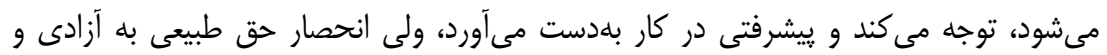

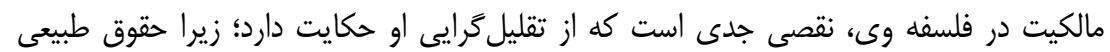

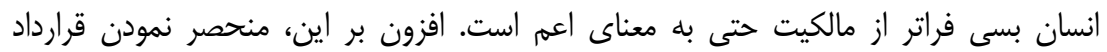

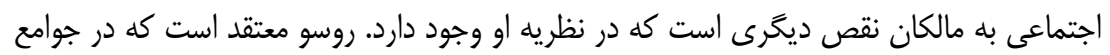
ابتدايى، مردم در هماهنگى كامل با طبيعت زندگى مى كنند و يبيدايش مالكيت، كشاورزى، و صنعت

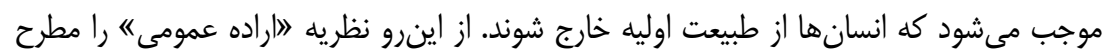

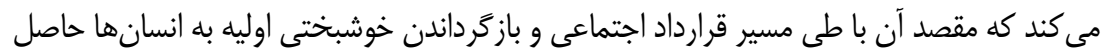
مىشود. روسو معتقد است عشق و ترحم دو سرجشمه احساس عدالتاند. ترحم، احساسى نسبى

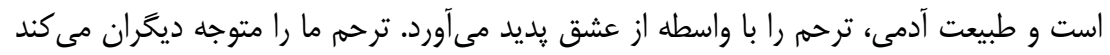


و همين توجه راه را بر نابرابرى عدالت مىبندد. ترحم كه فربه شود و به كمال رسل، به صورت فضيلتى درمىآيد كه عدالت نام دارد و حبّ نفس را تعميم مىدهد تا همه ابناى جامعه را را شامل

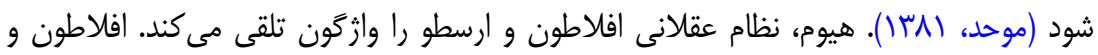
ارسطو، سلطه عقل بر قواى مختلف و توازن بخشيدن به آنها را عدالت معرفى مى كنند، ولى در الى إنى نظر هيوم، عقل در ااستخدام احساسات و عواطف و اميال طبيعى" است (Hume, 2003: 457). هيوم معتقد است در وضعيت طبيعى كه در جامعل، طبقات بر اساس مالكيت وجود ندارد، عدالت و

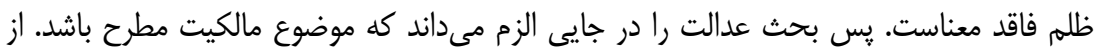
منظر او، جون در انسان گرايش به تصاحب نكردن مال غير وجود ندارد، نائزير براى تضمين ثبات

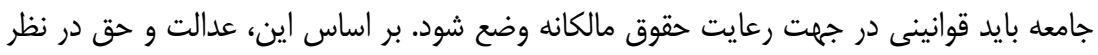

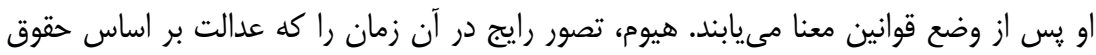

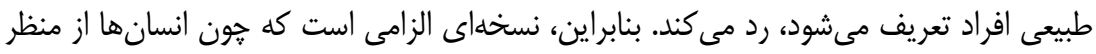

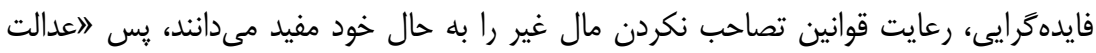
توجيه مىيابد، نه اين كه فضيلتى اخلاقى محسوب شوده (Hume, 2003: 619).

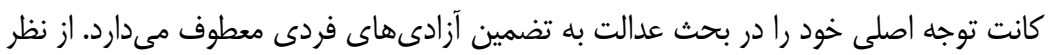

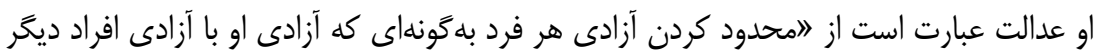

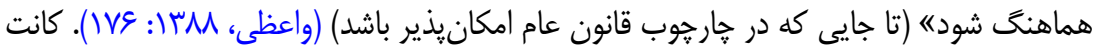

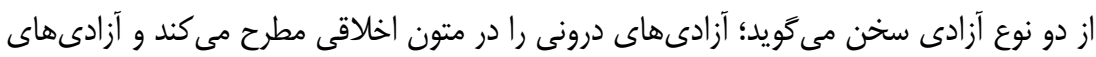

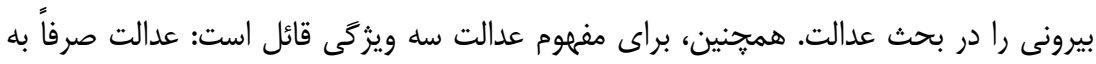

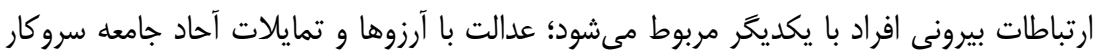

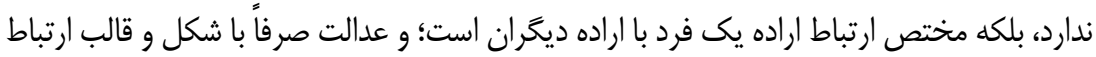

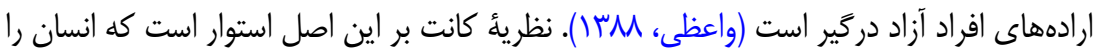

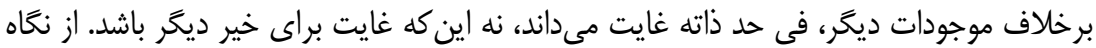

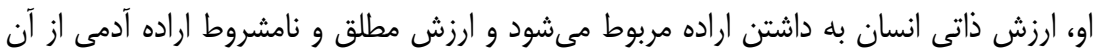

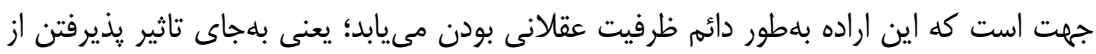

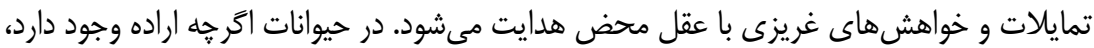
اما ارادة آنان ممكن نيست عقلانى باشد. حيوانات فاقد طبيعت و سرشت عقالانىاند. اراده عقالانى در انسان اين امتياز را براى او بلوجود مىآورد كه صاحب اراده خير باشد و اراده خير به معناى عمل إنل

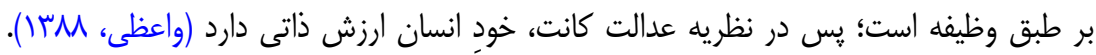


كانت، آزادى را بهدرستى كانون بحث عدالت قرار مى دهد، اما محدود كردن بحث عدالت به آزادى

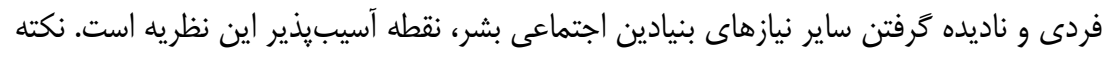

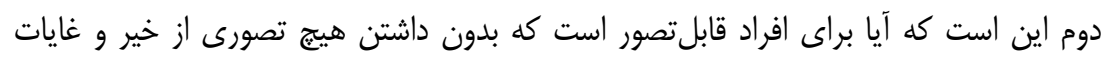

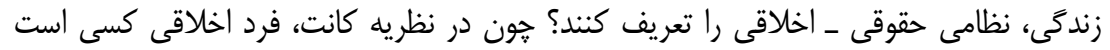

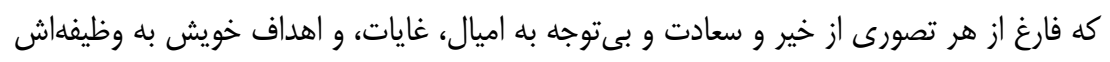

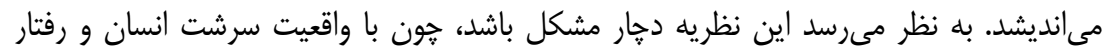

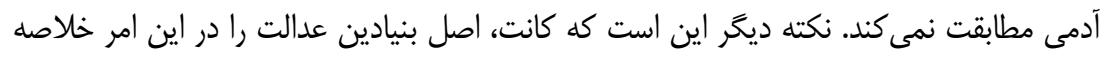

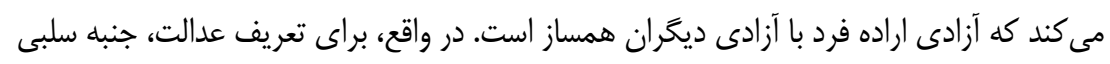

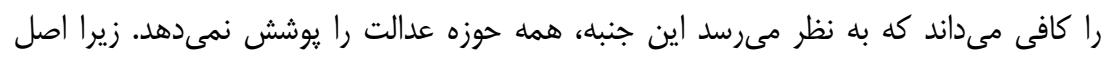

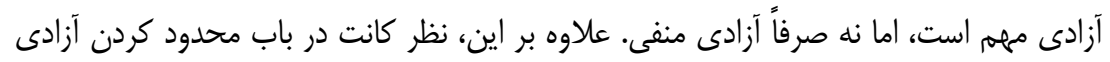

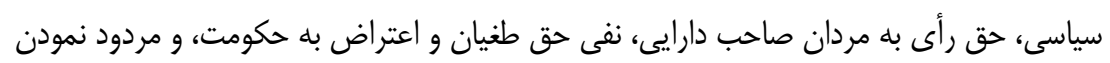

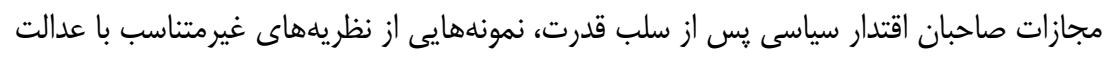

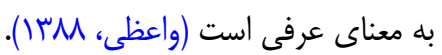

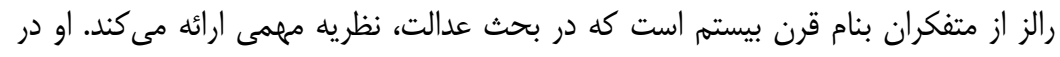

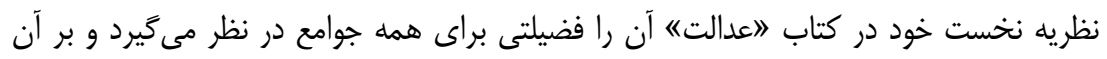

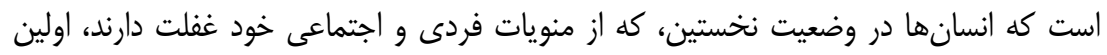

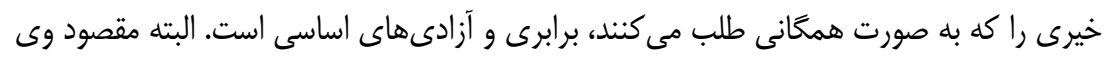

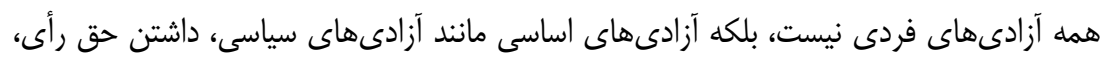

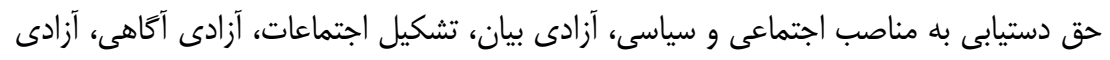

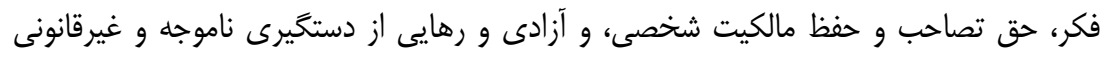

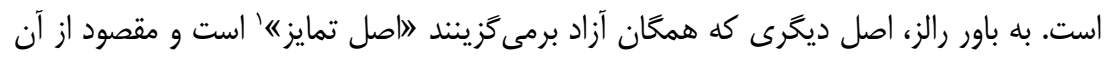

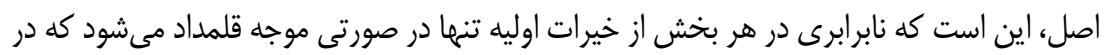

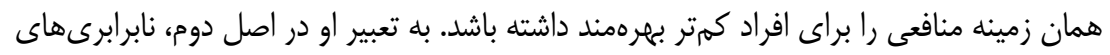

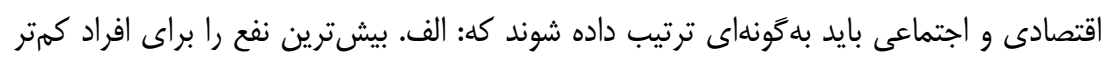

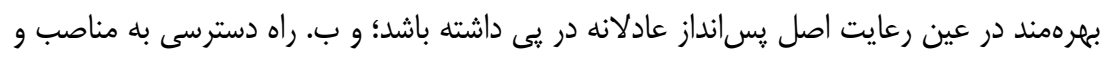

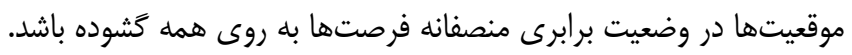

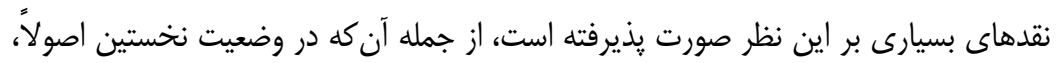

1. Difference Principle 
امكان جداسازى همه هويتها از افراد امكانيذير نيست. يكى ديخر از انتقادها بيان مى كند كه

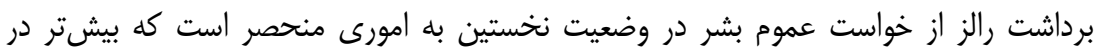

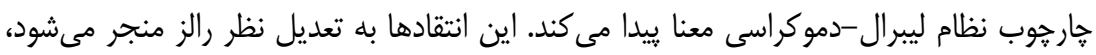

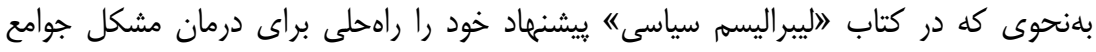

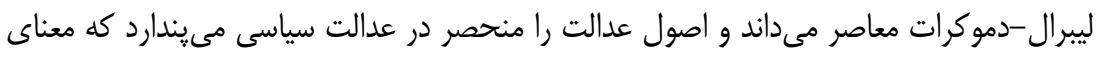

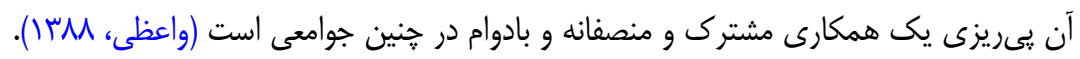

\section{نقدى بر عدالت اجتماعى در انديشه غرب}

بنابر توضيحهاى ييشين، رالز و سِن با تلاشهاى خود هر يك بحث عدالت را در وجهى توسعه

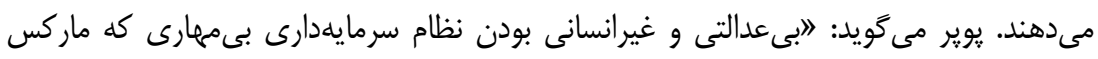

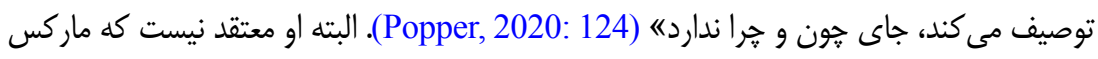

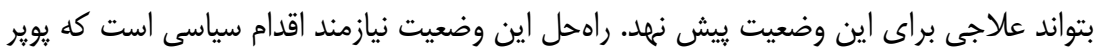

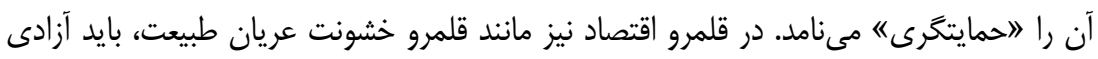

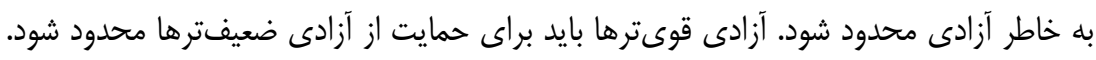

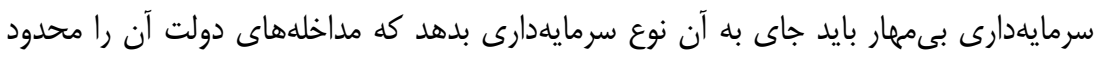

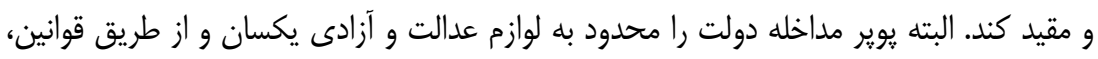

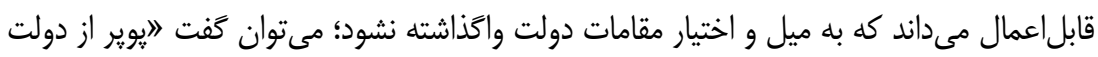

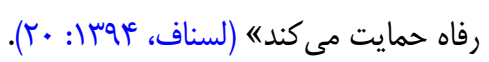

از مجموع بررسى آراى متفكران، اعم از فلاسفه سياست، متفكران اسلامى، و اقتصاددانان به به إنه

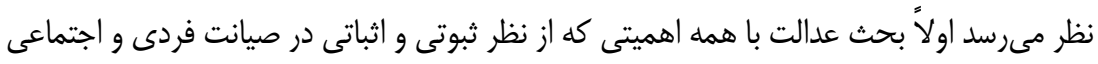

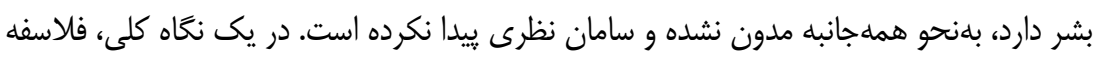

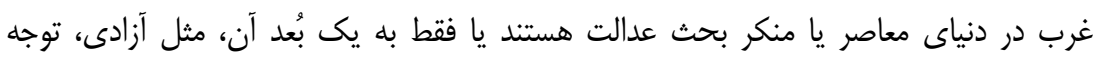

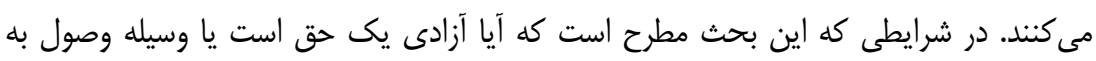

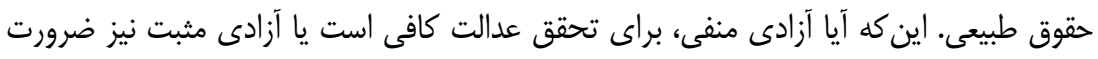

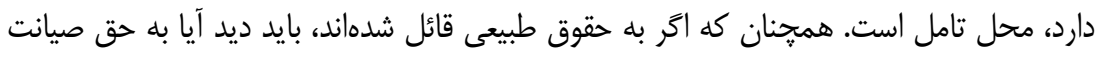

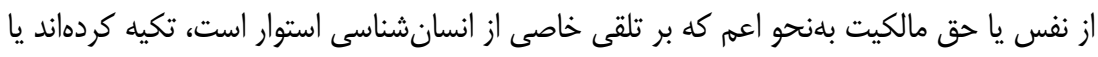

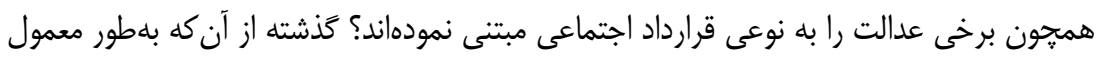

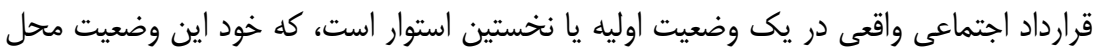


مناقشه جدى است، مهمتر از اين صحنه و وضعيت اوليه، مقوله خواست عمومى است كه از اين

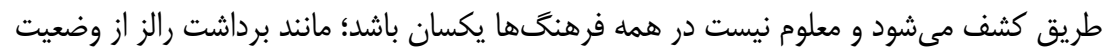

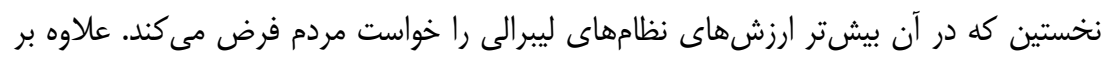
اين، بحث جدىتر وجاهت تعميم اين دريافت در عالم فرضى به صحنه عالم واقعى است كه به به

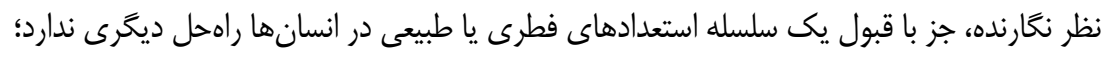

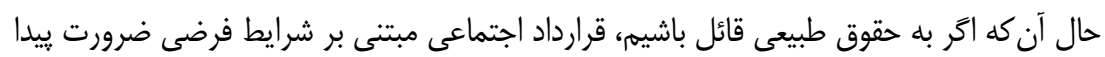

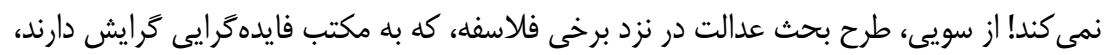

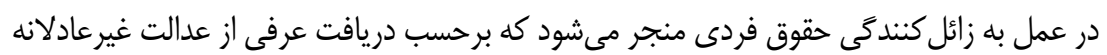

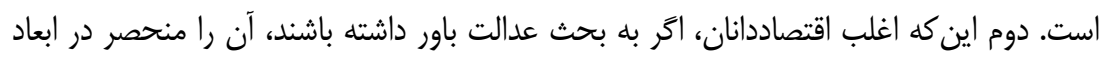

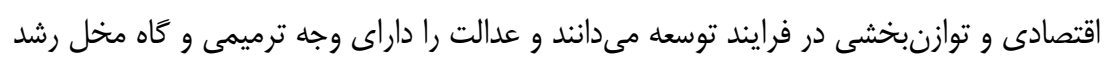

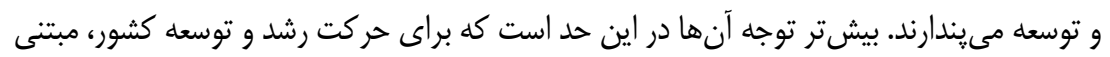

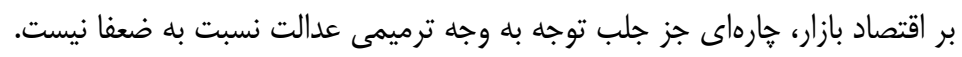

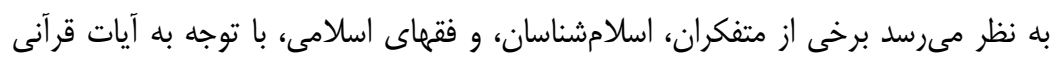

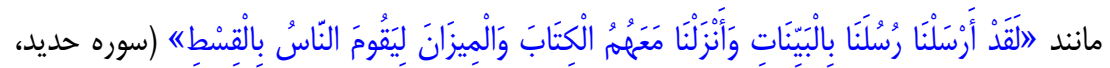

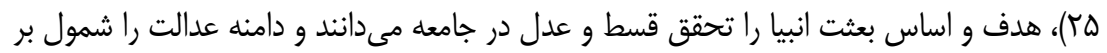

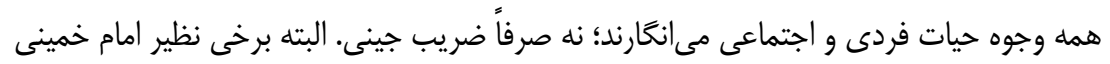

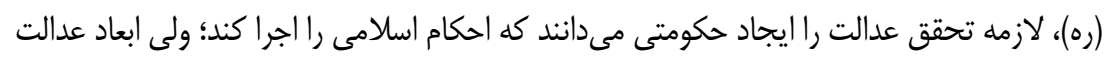

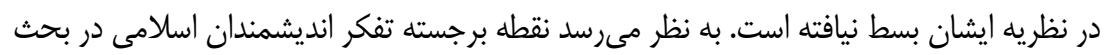

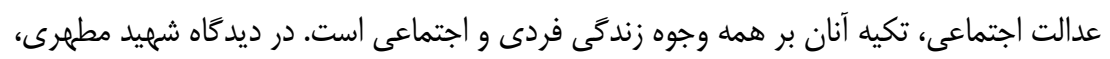

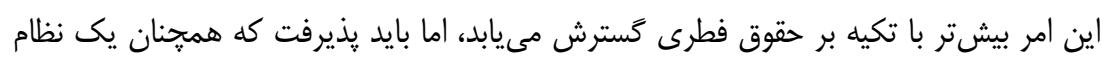
نظرى براى همين برداشت همهجانبه از عدالت اجتماعى بهدست نيامده است.

\section{عدالت اجتماعى در انديشة اسلامى}

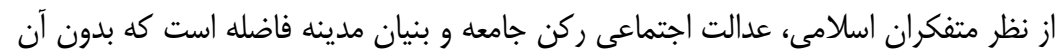

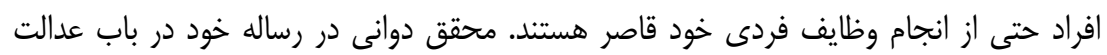

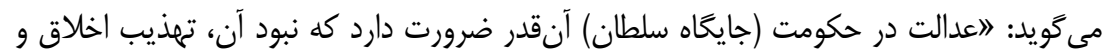

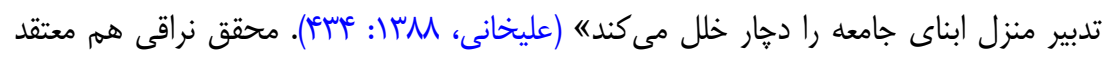

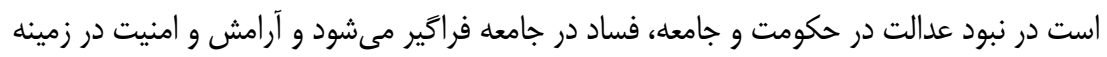


تحصيل دانش و كمالات رخت برمىبندد و صاحبنظران به انزوا كشيده مىشوند و جامعه افسرده و

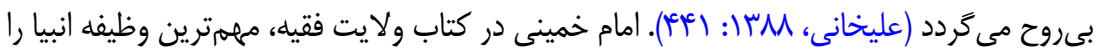

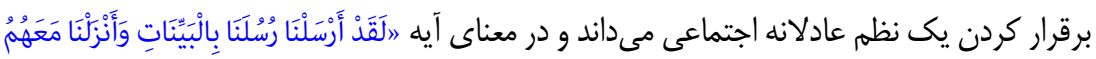

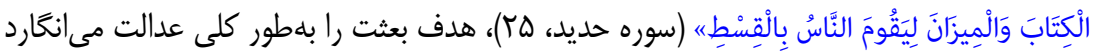

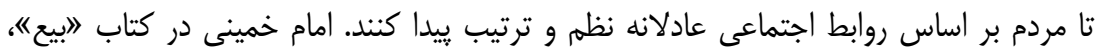
لازمأ تحقق عدالت را ايجاد حكومت عنوان مى كند و حتى احتمال مىدهد كه اسلام با همه شئون و لوازم آن حكومت است (السلام هو الحكومه در زبان ايشان يعنى همأ اسلام سياست است نه إنه

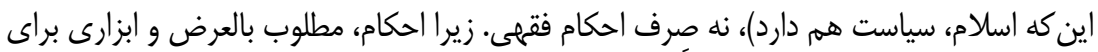

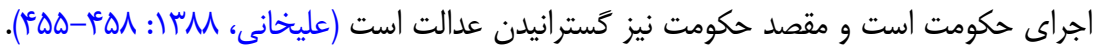

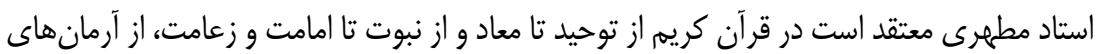

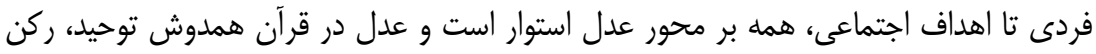

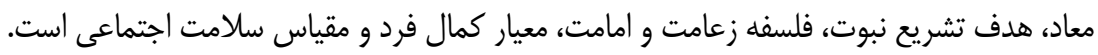

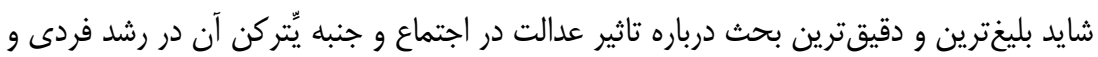

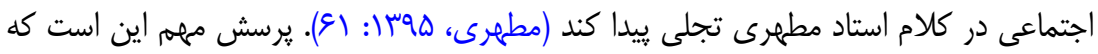

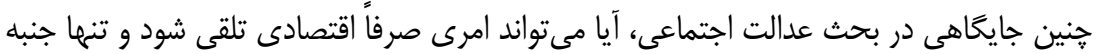

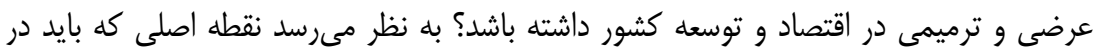
بحث از شرايط عدالت اجتماعى و رشد و توسعه اقتصادى مورد توجه قرار كيرد، همين امر است. به تهايه

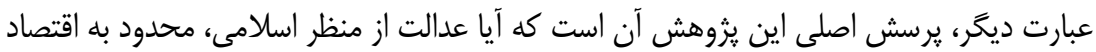

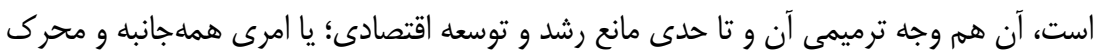
توسعه است؟ فرضيه (مدعا) اصلى مبتنى بر اين كزاره است: از منظر اسلامى، عدالت ناظر بر تمام

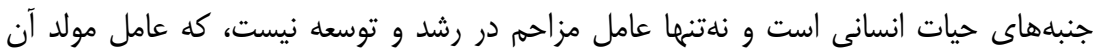
است. در قرآن كريه، آيات زيادى در باب عدالت و قسط وجود دارد و در مجموع در ها آيه، بحث

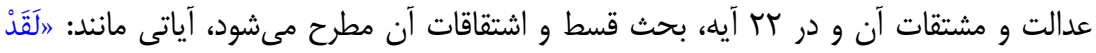

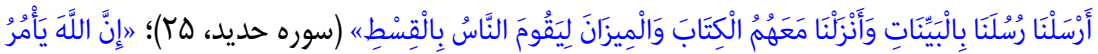

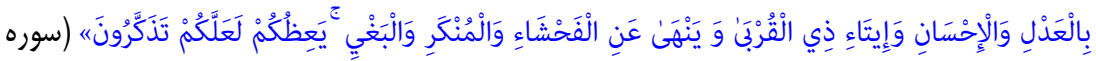

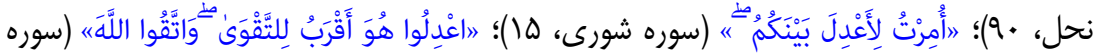

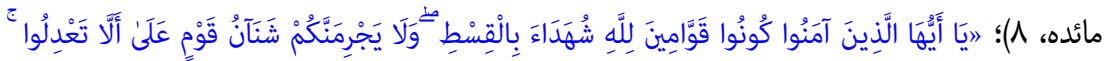

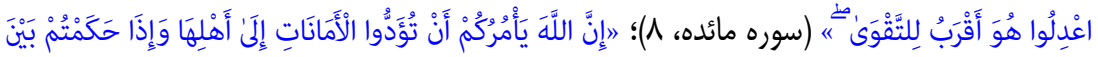




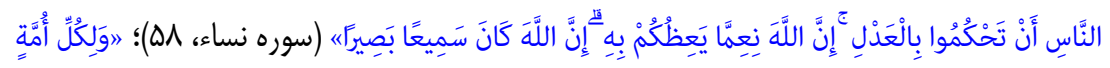

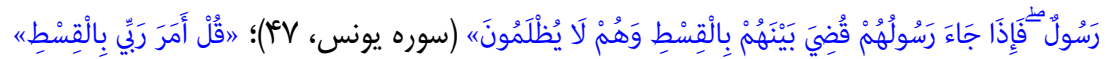

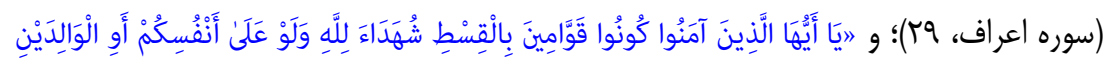

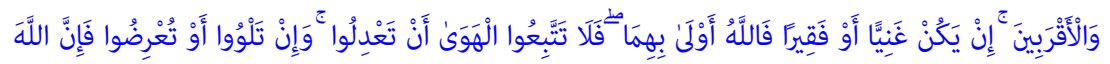

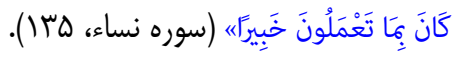

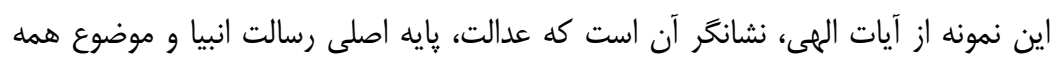

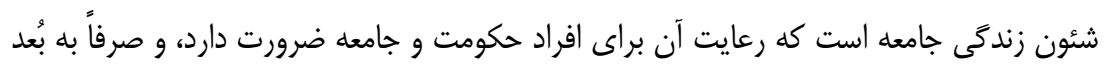

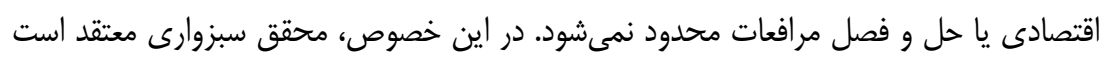

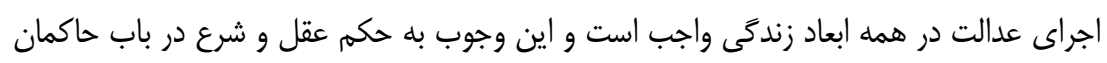

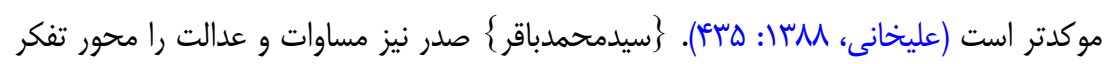

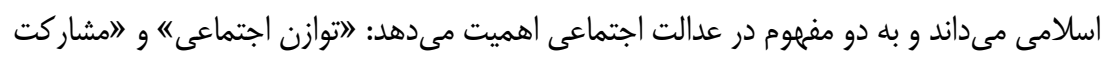

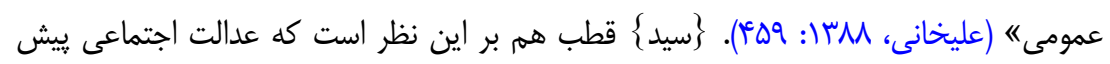

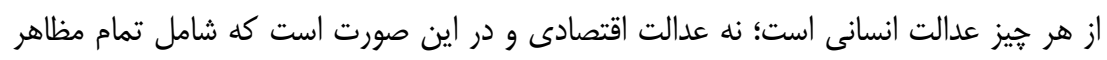

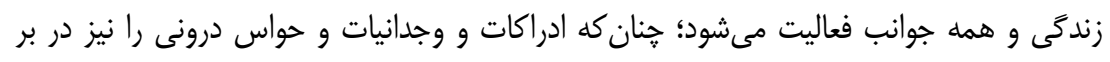

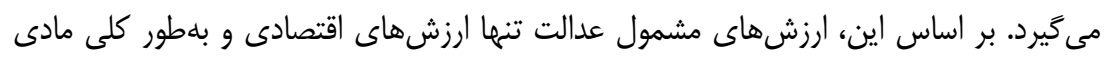

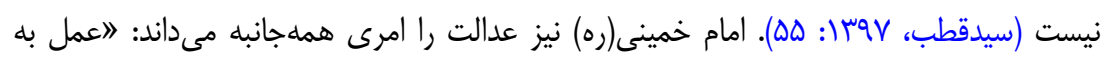

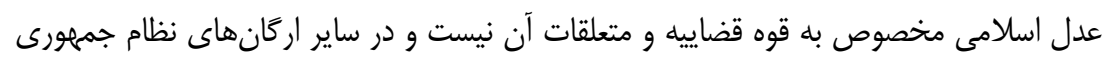

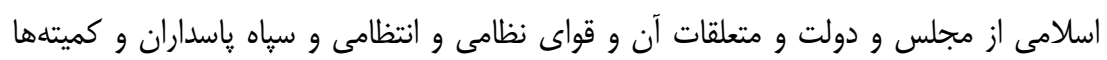

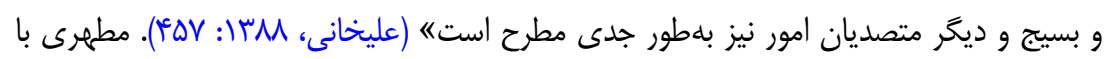

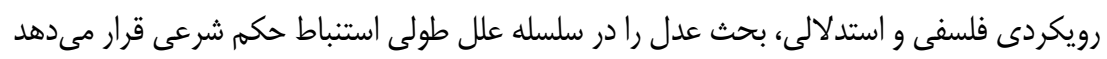

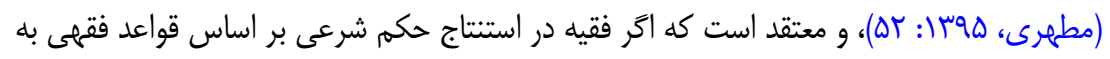

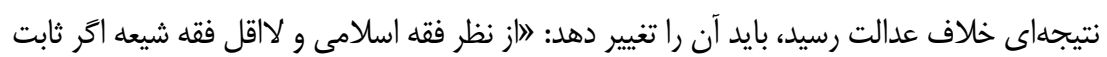

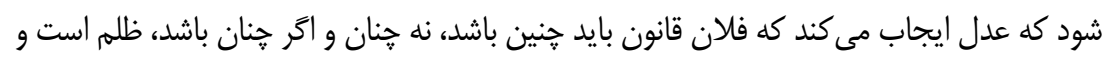

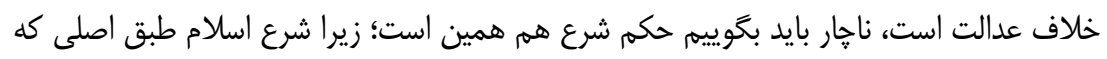

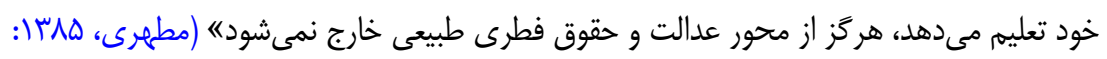

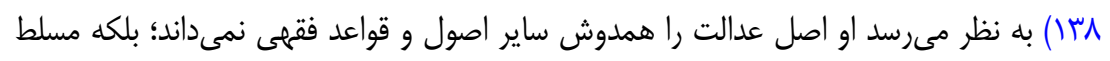

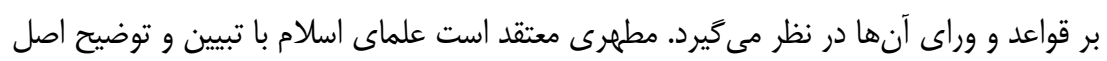

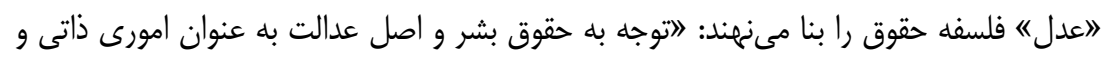


تكوينى و خارج از قوانين قراردادى، اولين بار به وسيله مسلمانان عنوان مىشود و پايه حقوق طبيعى

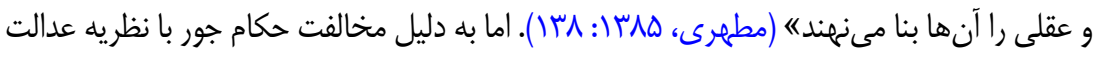

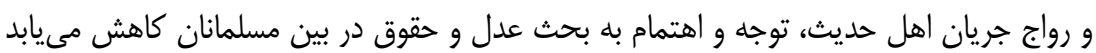
و بهجاى آن توجه به اخلاق غلبه يبيدا مى كند.

نتيجه و زبدهُ فقرة اشارهشده اين است كه از منظر اسلام بر اساس آنجه متفكران اسلامى بدان توجه مى كنند: الف. عدالت اجتماعى، يك امر همهجانبه است و ابعاد فرهنگى، سياسى، اجتماعى،

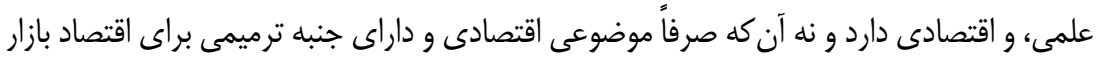

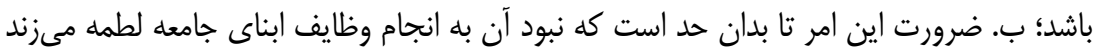

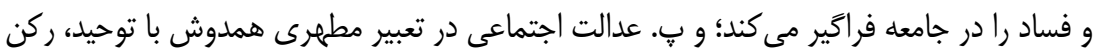

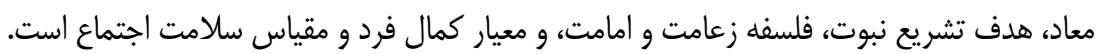

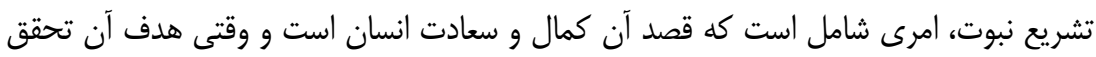

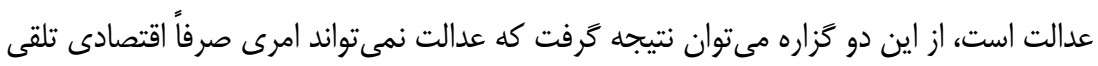

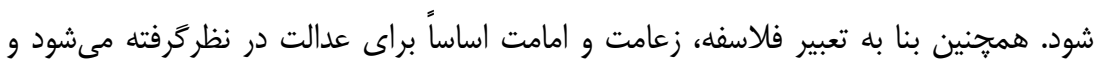

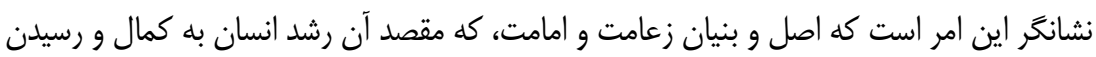

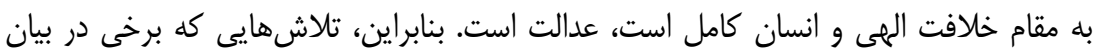
عدالت اجتماعى اسلام در تراز عدالت توزيعى يا تنظيمى (به تعبير ارسطو) مى كنند، به مثابه جدا شدن از اصل نظريه عدالت در نظام فكرى اسلامى است.

جارجوب مفهومى ثزوهش
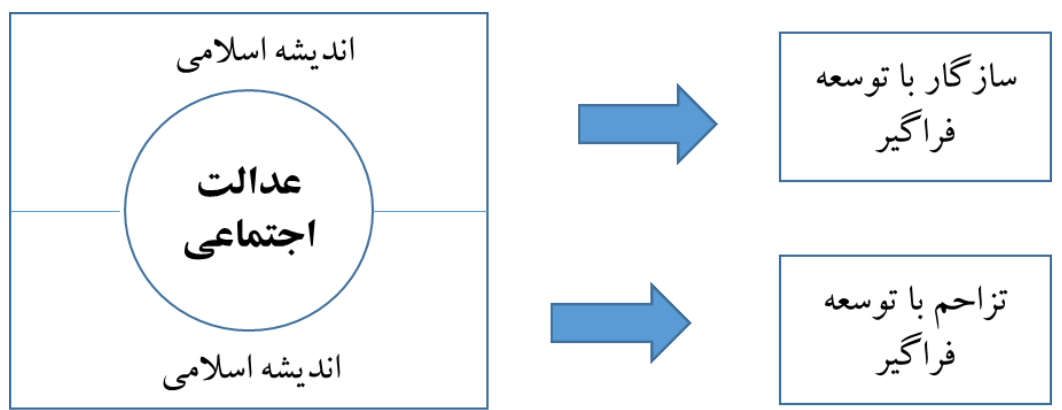

نمودار ا: جارجوب مفهومى تحليل 
با توجه به خار خوب مفهومى، يرسشهايى قابل طرح هستند:

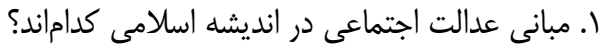

r. تا جه حد عدالت اجتماعى در انديشه اسلامى با توسعه فراكير ساز كار است؟ استى

\section{روش}

اين تحليل بر اساس خارخوب مفهوم نظام معانى مى كوشد با استفاده از تفكر انتقادى به يرسشهاى اشارهشده پاسخ دهد. بنابراين، از نظر روششناختى يكى تحليل نظرى است كه سعى إسى

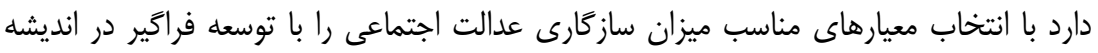
غربى و اسلامى مقايسه كند.

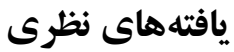

با توجه به هار :وب مفهومى، تحليل هاى فلسفى زير در ارتباط با برسشهاى يزوهش قابل ارائه

هستند:

\section{ابعاد و مولفههاى عدالت اجتماعى از ديدكاه اسلام}

الف. بايه بحث در مقوله "عدالته به معناى عام و "اعدالت اجتماعى" به معناى خاص را بر

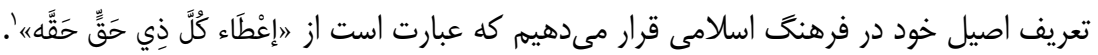

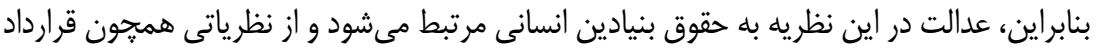
اجتماعى يا فايدهر ايیى فاصله مى گيرد.

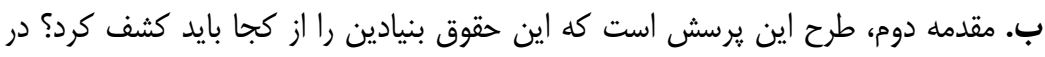

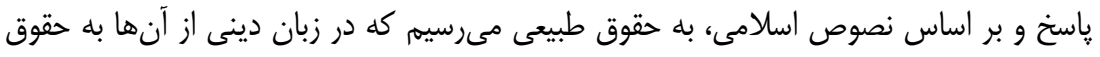

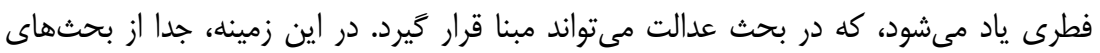

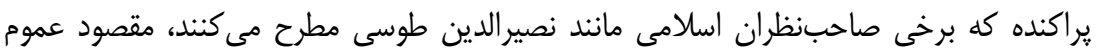

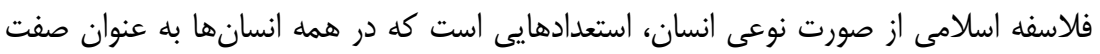

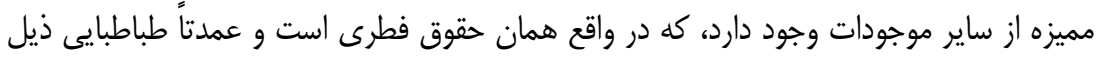

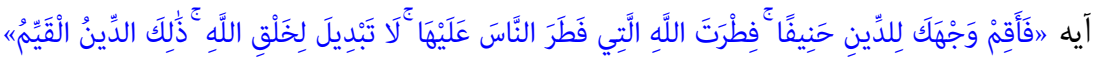

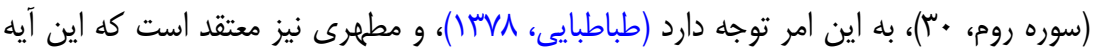




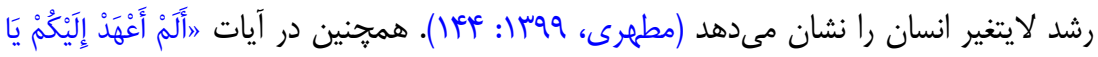

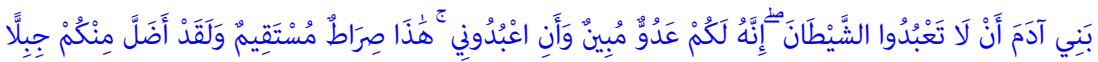

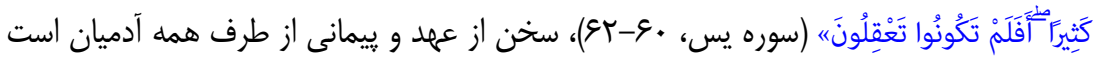

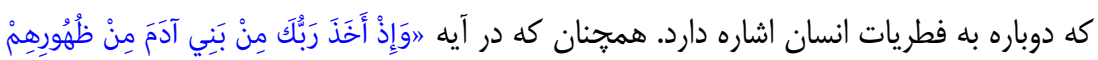

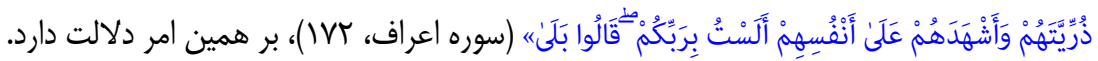

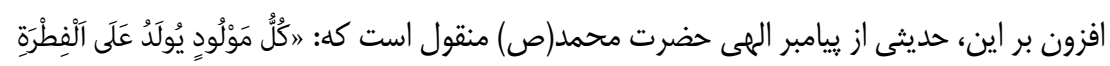

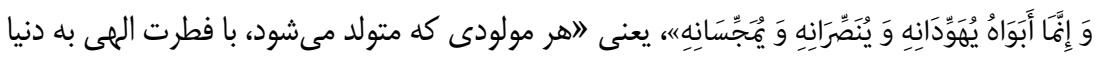

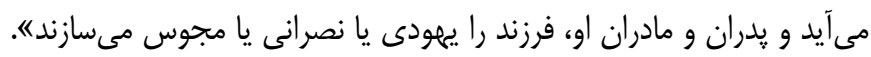

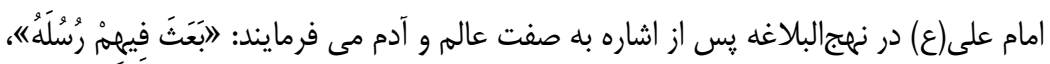

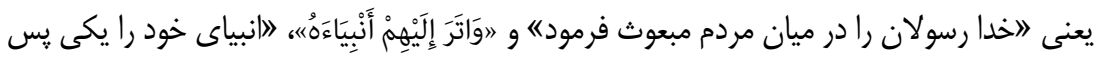

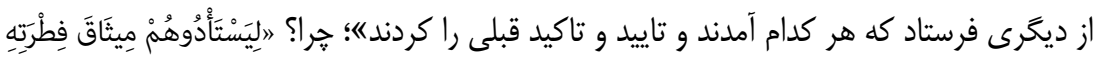

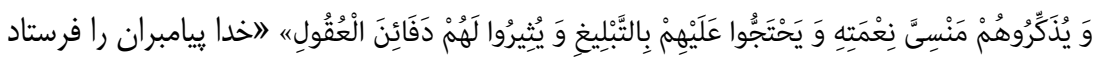

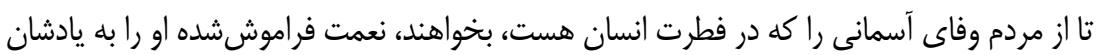

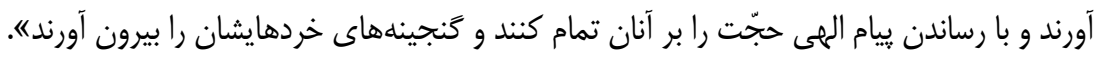

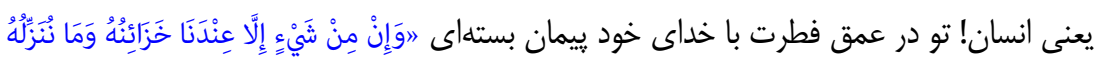

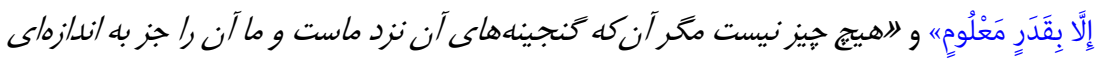

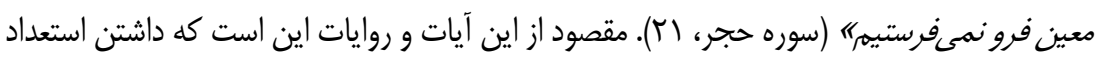

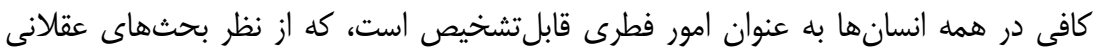

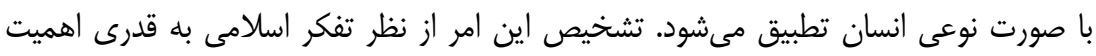

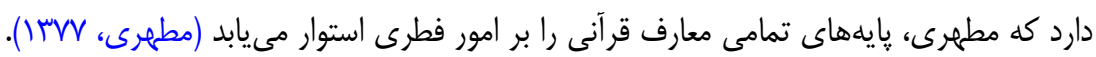

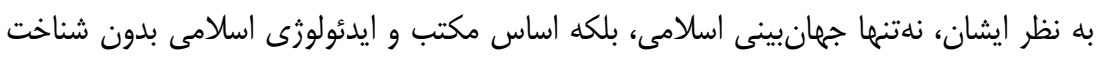

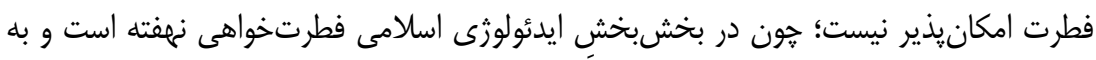

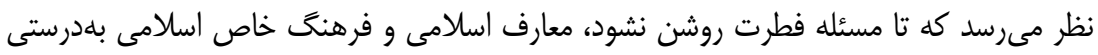

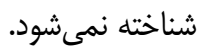

اكنون ممكن است اين برسش مطرح شود كه نظريه فطرت به عالم شناخت مربوط است، حال

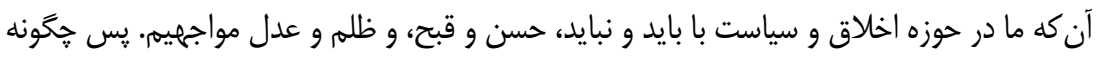

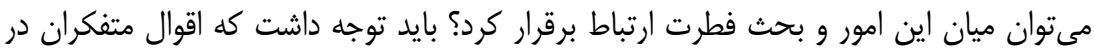

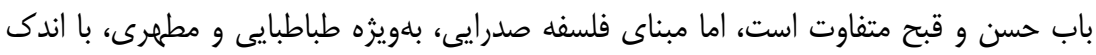


تفاوتهايى اينَّونه دستهبندى مى شود: اولاً حسن و قبح مربوط به ذات فعل انسانى نيست؛ ثانياً

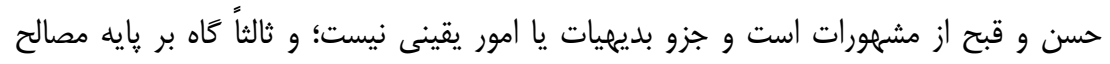

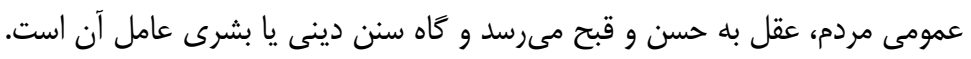

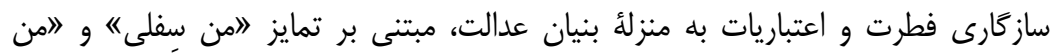

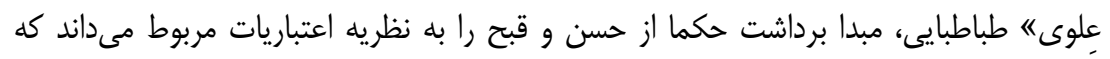

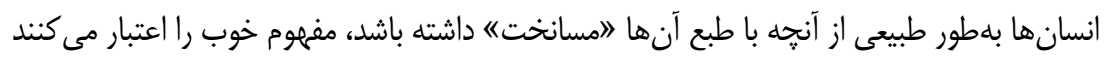

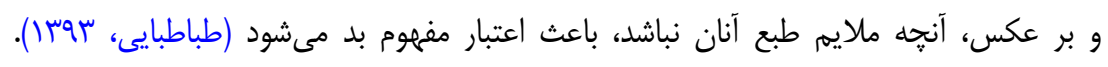

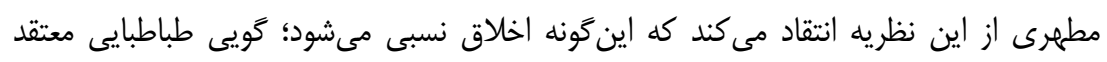

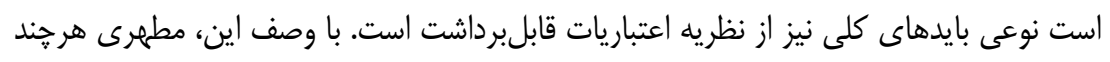

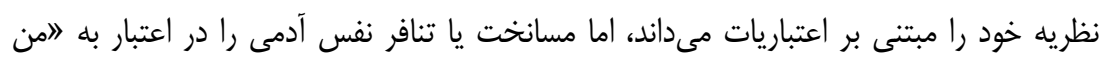

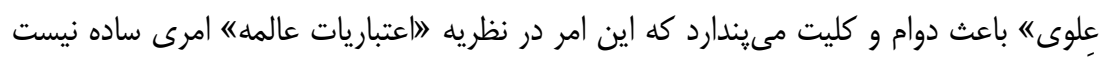

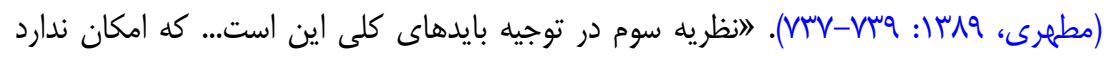

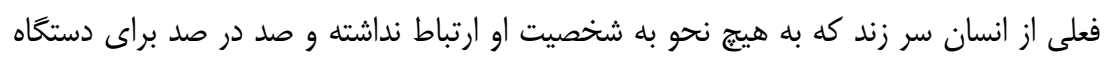

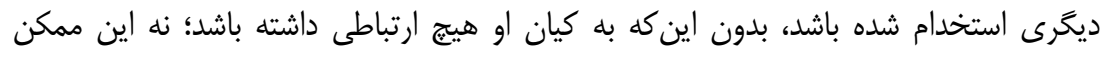

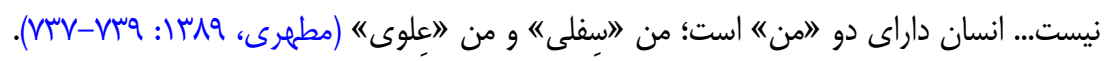

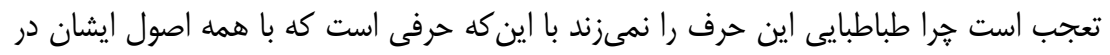

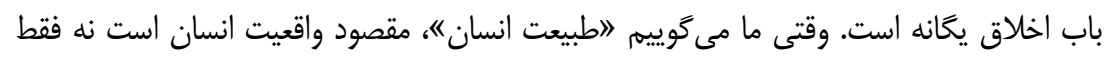

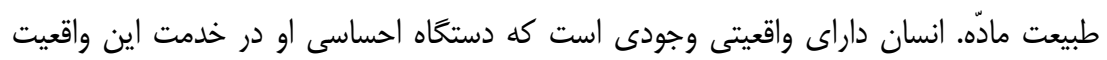

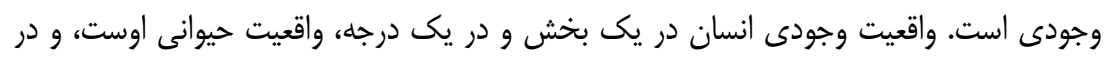

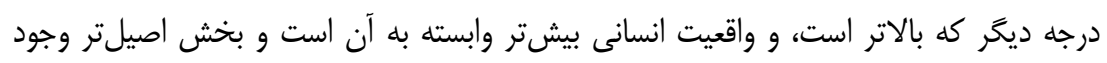

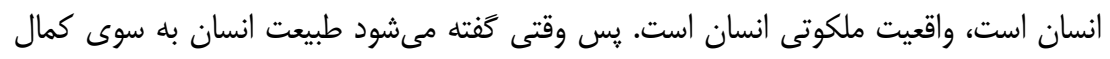

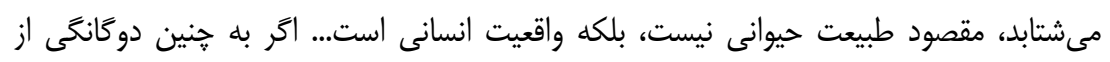

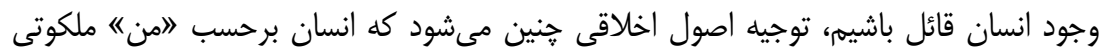

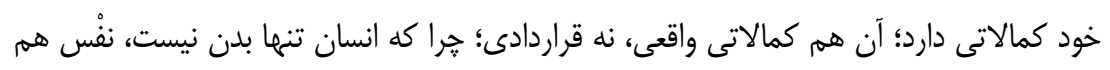

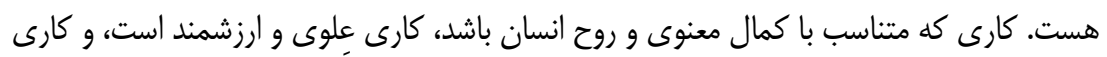

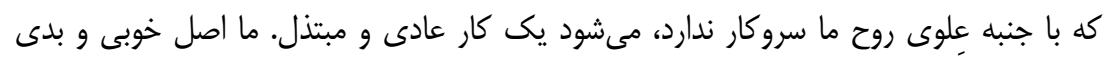

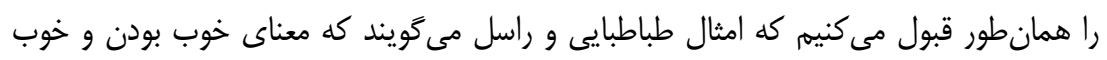

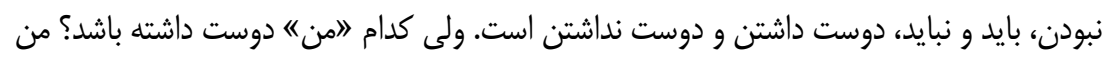




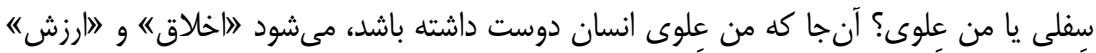

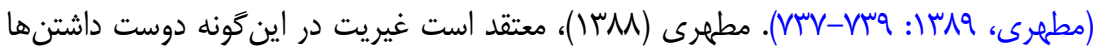

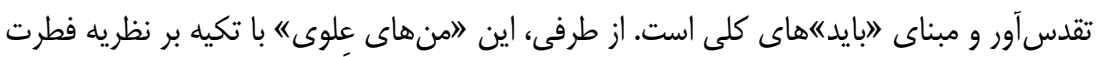

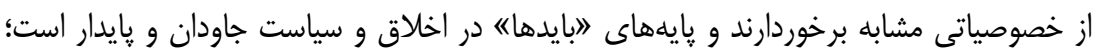

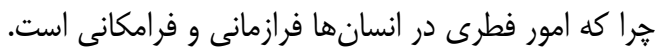

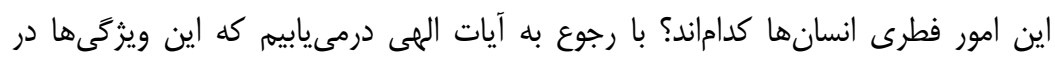

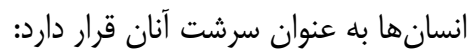

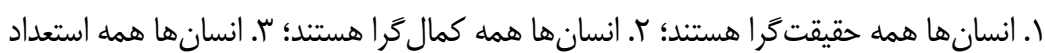

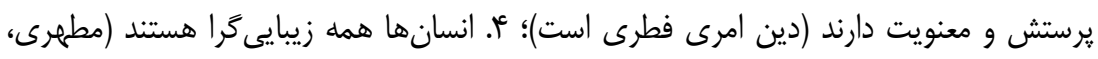

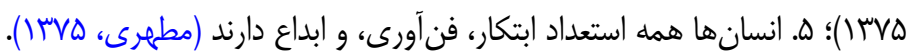

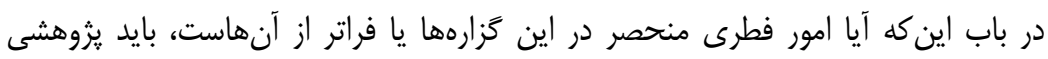

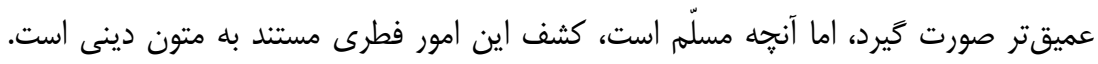

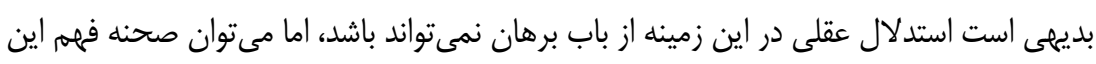

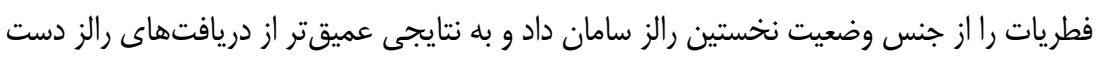

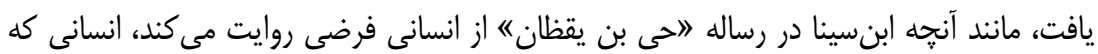

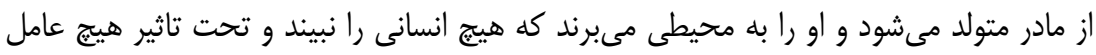

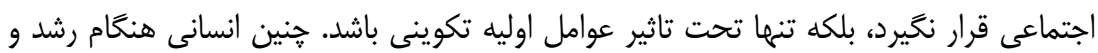

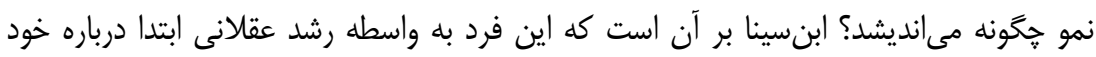

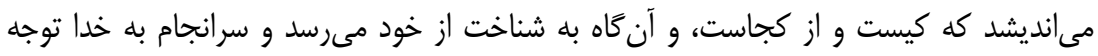

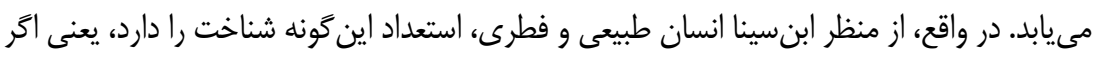

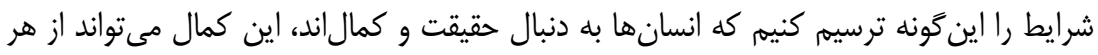

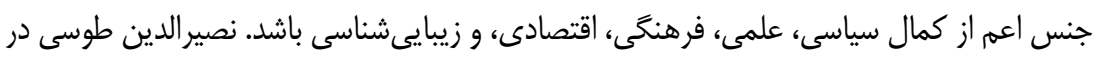

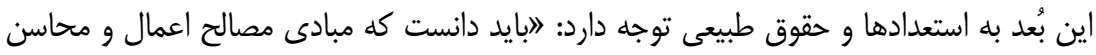

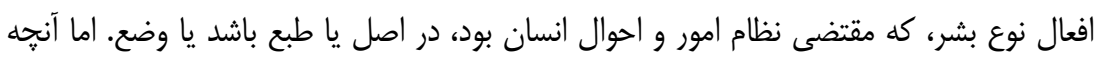

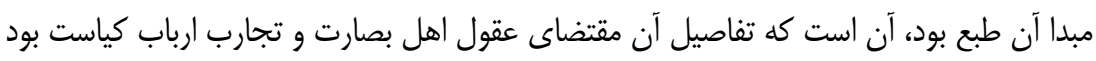

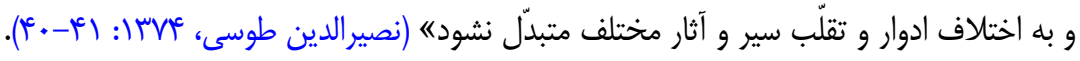

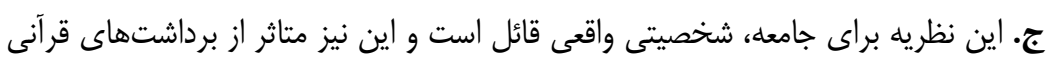

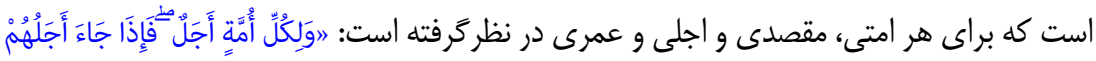




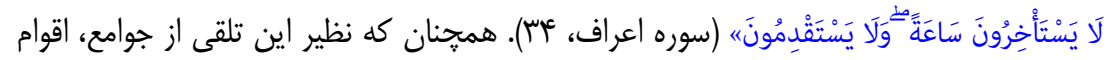

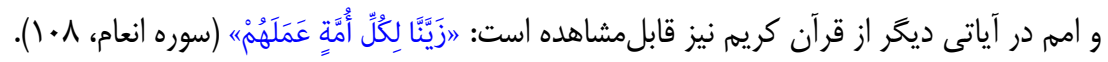

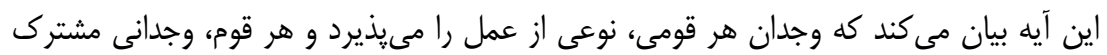
دارد. مستفاد از اين آيات، به نظر مطهرى تركيب جامعه، تركيبى حقيقى است.

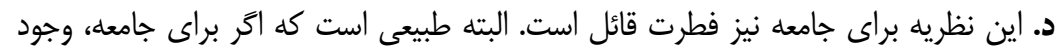
حقيقى قائل شويم و انسانها كه سازنده اين وجود هستند، از استعدادهاى فطرى برخوردار باشند، جامعه نيز از سنن و قوانين ثابت برخوردار مىشود كه در هدايت فرد تاثير خواهد كذاشت. در همين

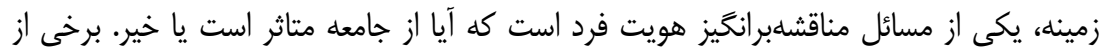

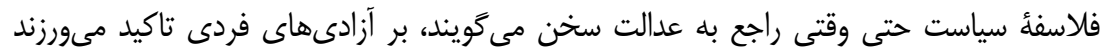

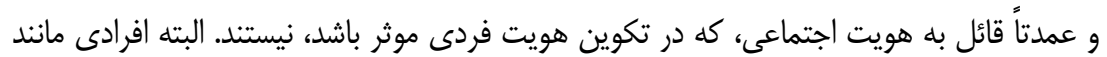

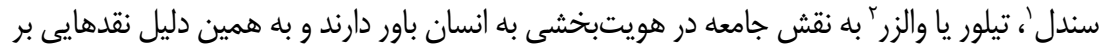

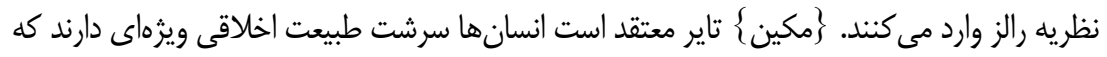
اهداف و غاياتى معين را تعقيب مى كنند و اين فضايل اخلاقى، كه ريشه در سرشت آدمى دارد، هركز

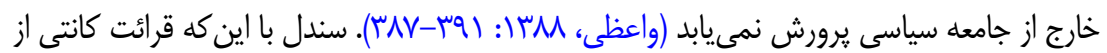

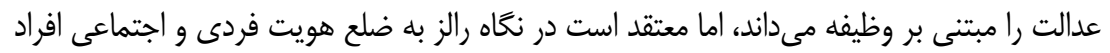
در شرايط نخستين از نظر متافيزيكى و هستىشناسى توجه نمى كند و نكاه او به جامعه، ابزارى است

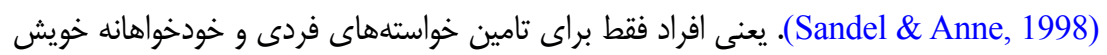
به اجتماع رومىأورند، و خير جامعه جيزى نيست جز مزايايى كه افراد در فرايند ييكيرى اهداف

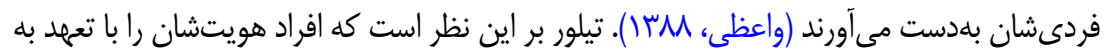

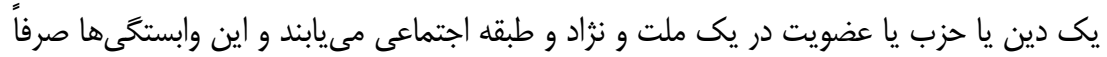

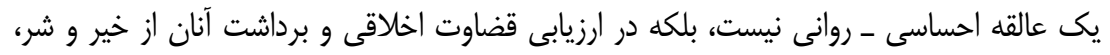
و درست و نادرست بسيار موثر است (Taylor, 1989). پِ معتقد است الاستقلال افرادى كه رالز آنان را در وضعيت نخستين، مستقل از تعلقات اجتماعى مىانغارد، در عمل امكانيذير نيست و آدمى آنا نمىتواند بدون ييشتصورى از خير و فارغ از جهت

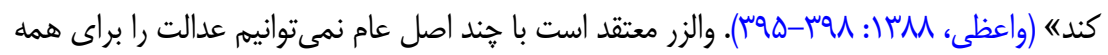

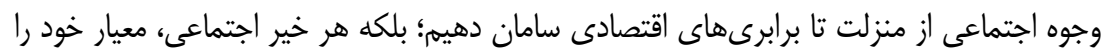


دارد و عدالت به وجهى، آفريده جامعه سياسى خاص در عصر خاص است. همين تصور از عدالت در

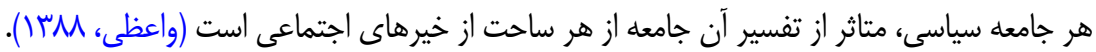

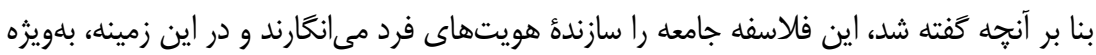

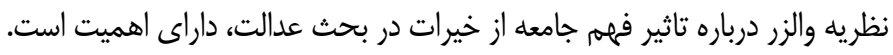

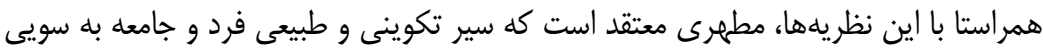

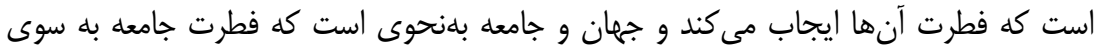

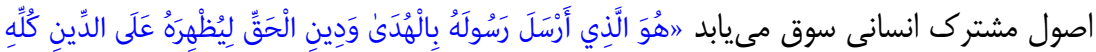

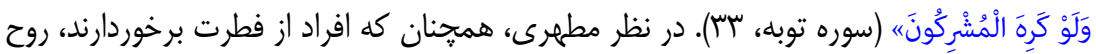

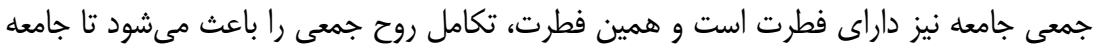

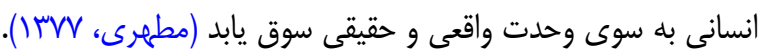
هـ امور فطرى جوامع קه امورى هستند؟ امور فطرى جوامع نظير استقلالخواهى، داشتن

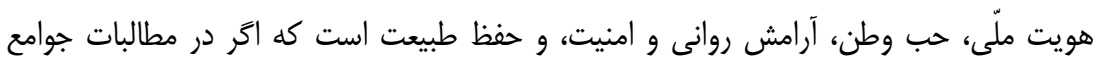

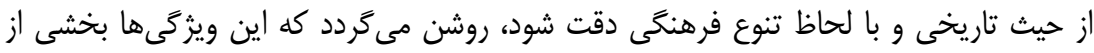
خواستههاى همه جوامع است. حال ممكن است مسلمانان هويت اسلامى را نيز براى اين خواستهها بيافزايند، اما در همه جوامع اينَونه ويزَىها عام است. براى نمونه، در باب استقلال خواهى،

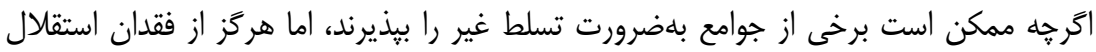
سياسى يا اقتصادى يا علمى خوشنود نيستند، خنين جامعهاى مانند فردى است كه طالب الب علم است، اما امكان تحصيل براى وى فراهم نيست؛ يا طالب آزادى است، اما امكان دستيابى به آن را ندارد.

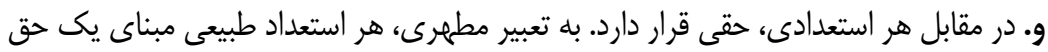

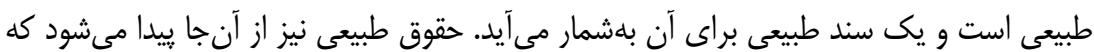

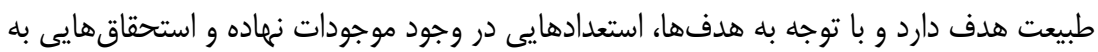

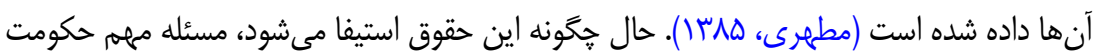
در اينجا نهفته است. وظيفه حكومت در نظريه عدالت اجتماعى عبارت است ازئ ا. زمينهسازى اله تحقق استعدادهاى طبيعى ابناى جامعل: حقوق افراد جامعه بايد محقق شود، البته نقش حكومت

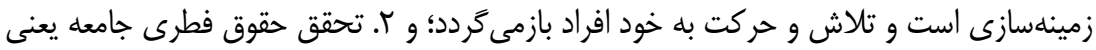

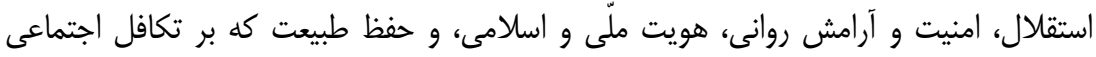

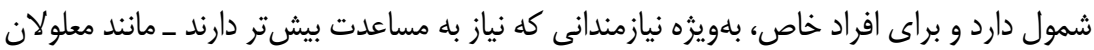




\section{آيا عدالت اجتماعى در نكاه اسلام با رشد و توسعه تزاحم دارد؟}

ز. از آنجا كه اين استعدادهاى فطرى جنبه بالقوه دارد، فعليت آنها متكى بر حركت است،

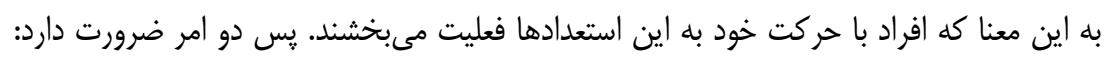

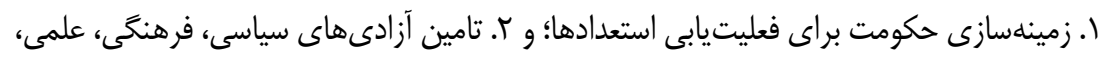

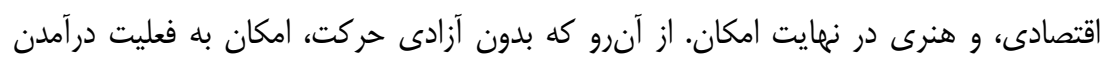

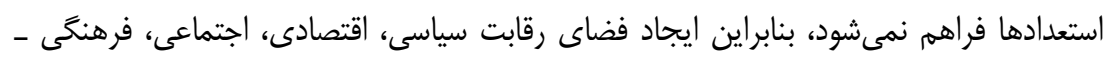

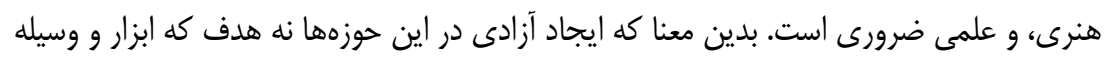

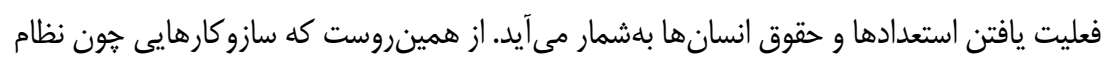

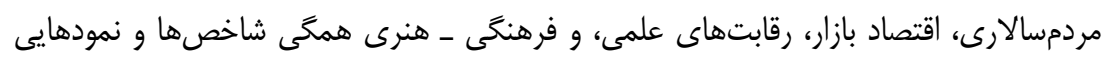

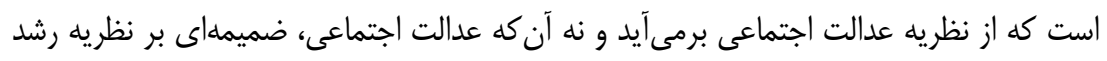
و توسعه جامعه و فرع بر آن باشد.

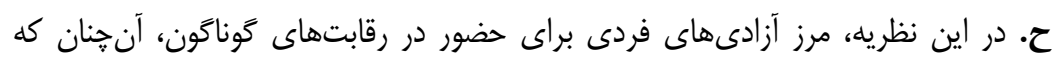

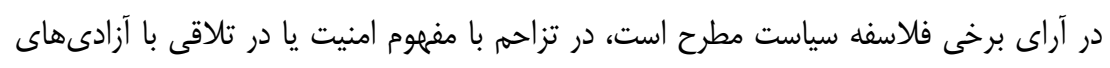

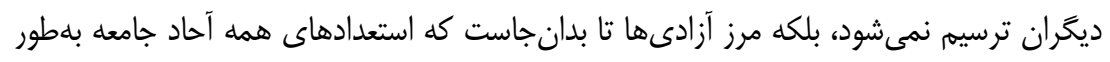

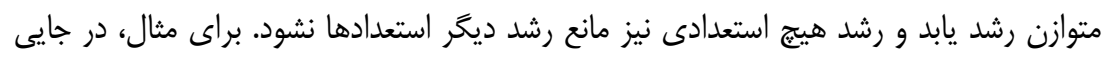

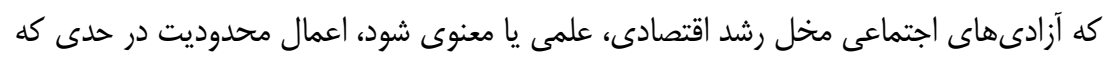
به رفع اين اخلال بيانجامد، ضرورت مى إبابد.

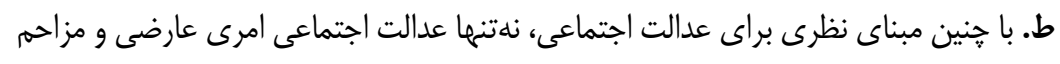

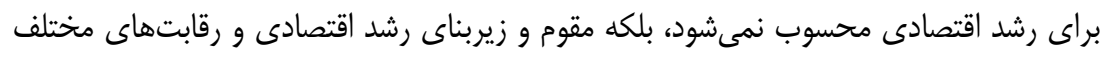

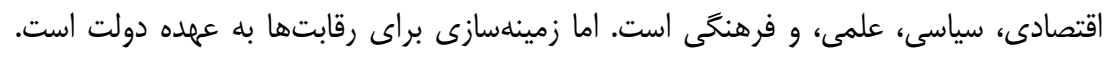

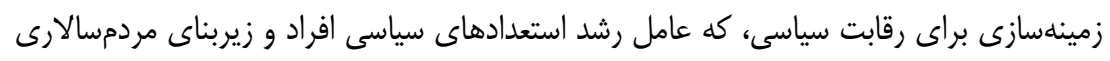

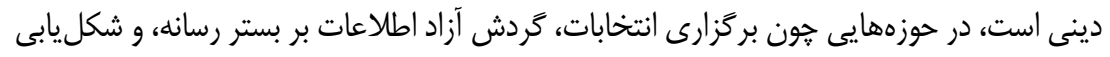

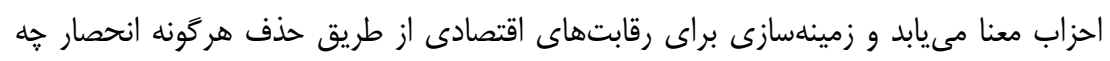

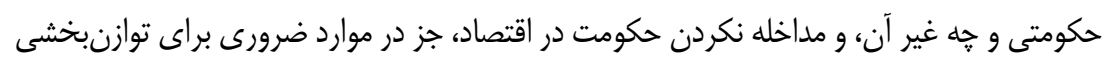

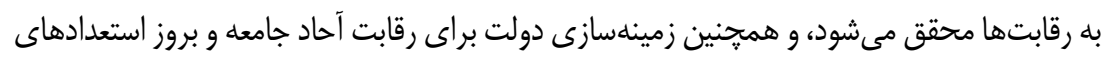
فطرى آنان در امور علمى، فرهنكى، و هنرى. ى. در جهت تحقق اين نظريه، اقدامهاى ضرورى حكومت فرى براى رقى رقابت همهجانبه به اين شرح 
است: ا. تدوين و اجراى طرح آمايش سرزمين بلهنوى كه امكانات اوليه براى حضور همخان در

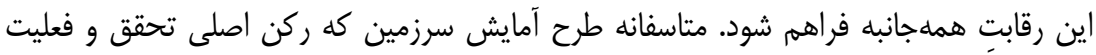
استعدادها و حقوق فطرى جامعه در حوزههاى آموزش، بهداشت، و فعاليتهاى اقتصادى است، در كشور ما هنوز تدوين نشده است. دليل اصلى بىعدالتى در جامعه ايران نيز به كمكارى مربوط

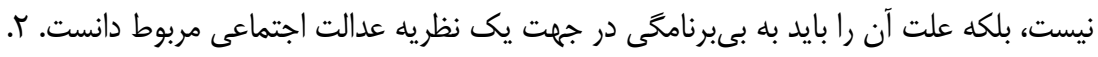

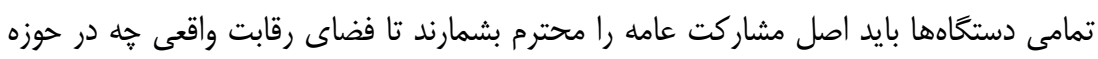

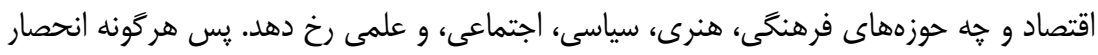

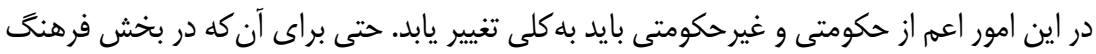

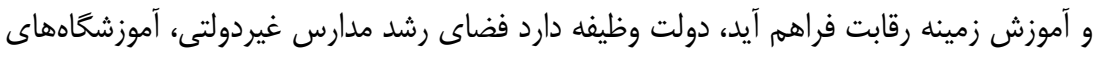

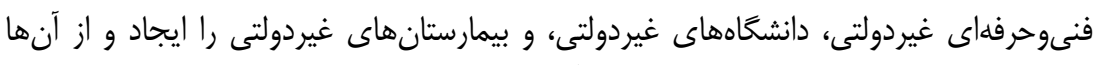

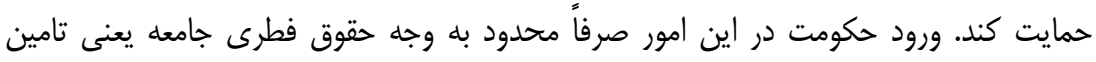

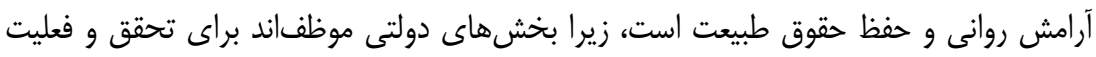

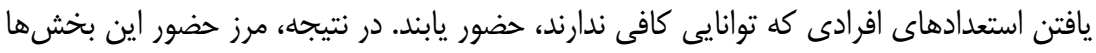

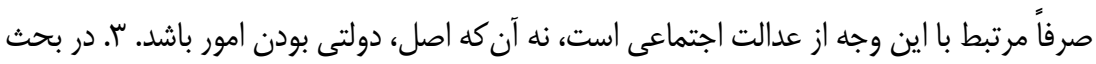

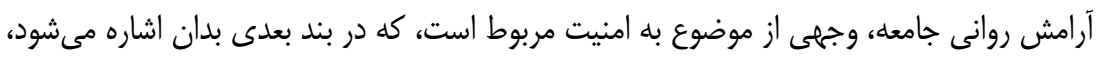

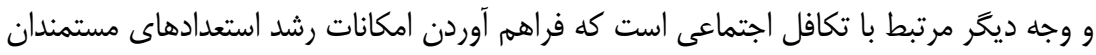

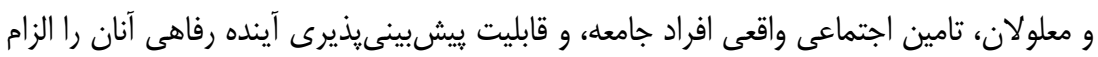

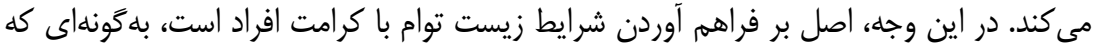

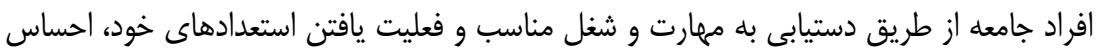
ييشرفت و حركت كمالى داشته باشند. به اين ترتيب، بخش اعظه كار دستخاههاى امدادى، نه

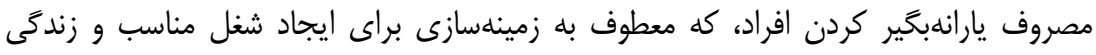

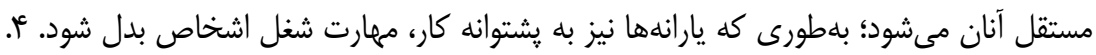

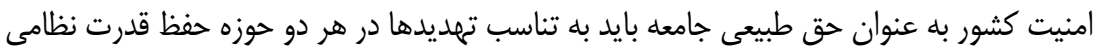

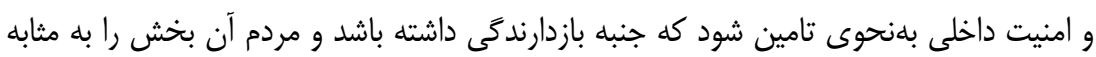

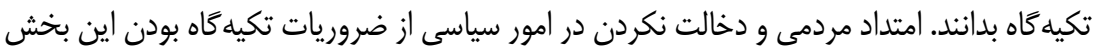
محسوب مىشود. ه. حفظ هويت ايرانى ـ اسلامى از حقوق فطرى جامعه محسوب مى شيود كه

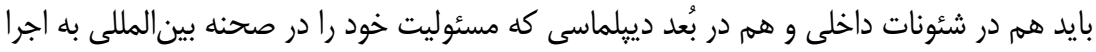

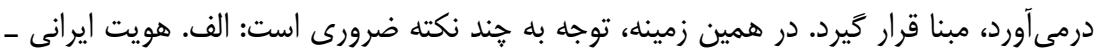


اسلامى جامعه در بُعد داخلى بر محور مشار كت عامه تحقق مىيابد كه اين وجه نياز به تقويت دارد؛

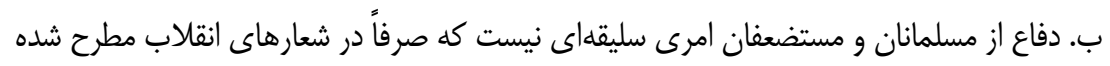

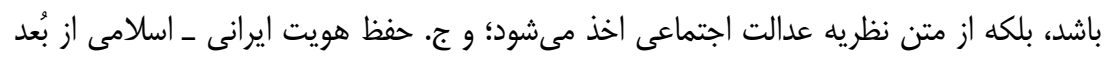

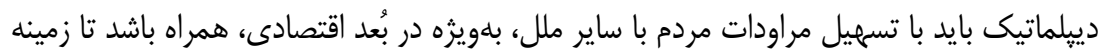

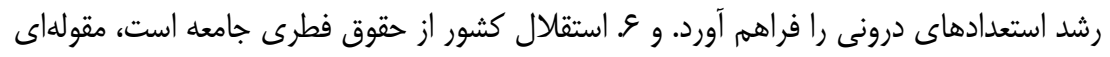

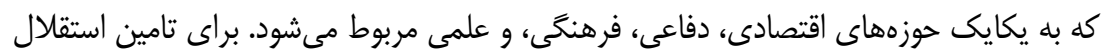

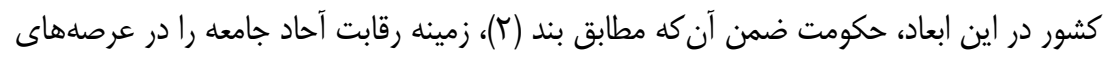

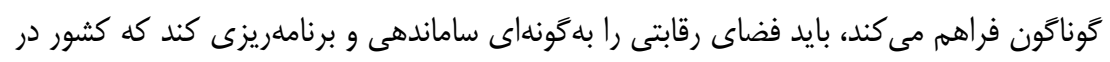
كلان به خودكفايى در اين امور نائل آيد.

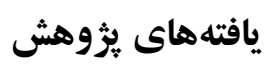

\section{مقومها و اركان نظريه عدالت اجتماعى اسلام}

ركن نخست: در تدوين اين نظريه از (نظريه فطرت) طباطبايى و مطهرى استفاده مىشود،

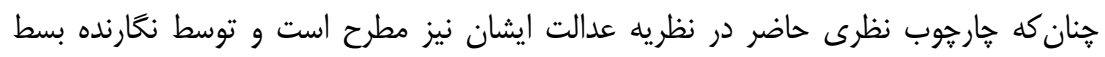
مى ميابد.

ركن دوم: ممكن است كسى نظريئ ييشارو را صرفاً براى كشورى با انكَيزه اسلامى و نه براى

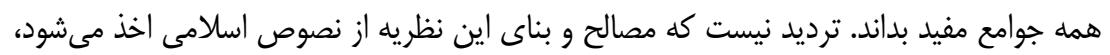

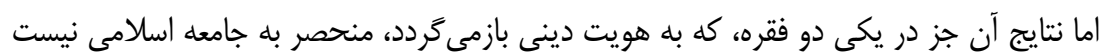

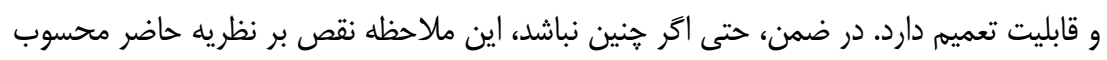

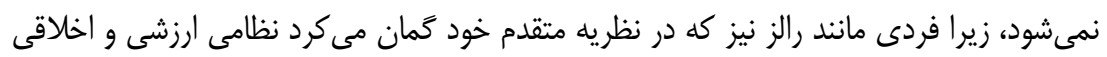

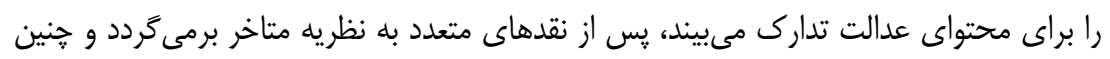

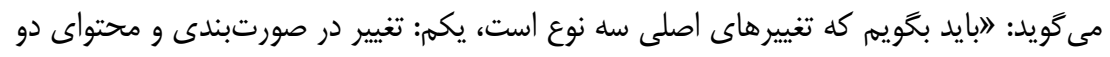

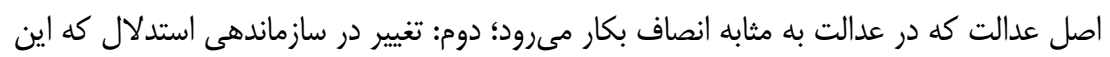

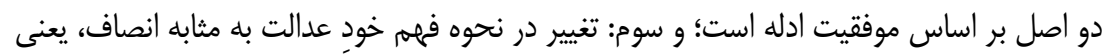

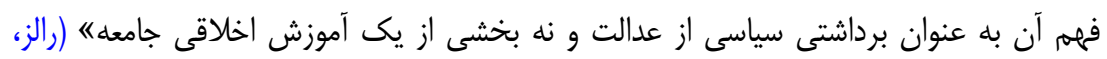

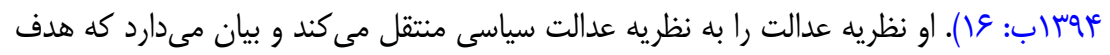

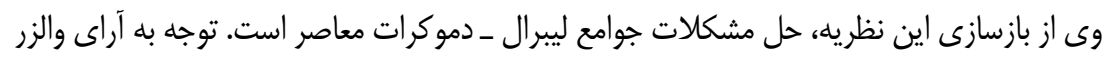


در باب عدالت روشنحَر معنايى مهم است و آن اين كه تصور از عدالت در هر جامعه سياسى، متاثر از تفسير آن جامعه از ساحات مختلف خير اجتماعى است (Walzer, 2008). هرجند والزر قائل به

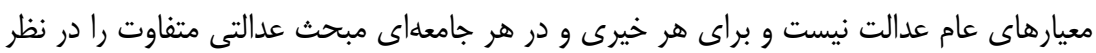

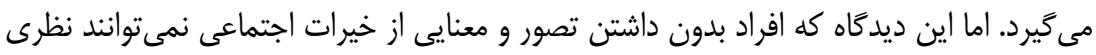

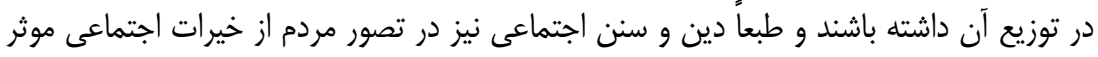
است، حرف سنجيدهاى است. البته ما نمىتوانيم در همه بخشها نظريه والزر را تاييد كنيه، جرا كه

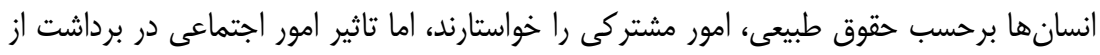
اين امور نيز تا حدى انكارنايذير است.

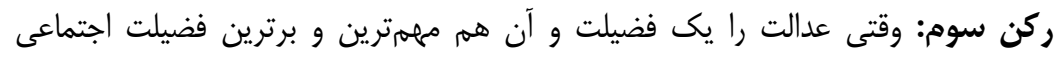
بدانيم (Rawls, 2009)، تصديق مى كنيم كه فضايل مرتبط با حوزه ارزشها بلهطور عام متاثر

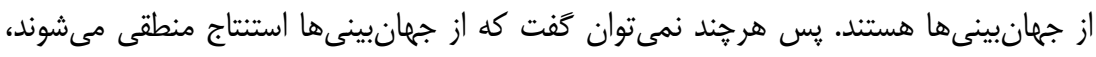

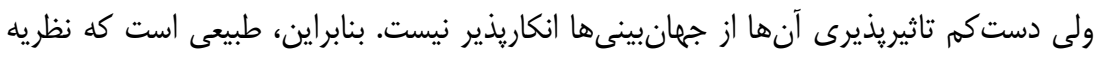

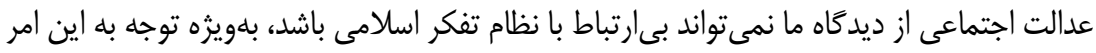

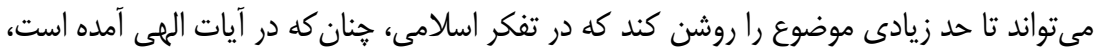

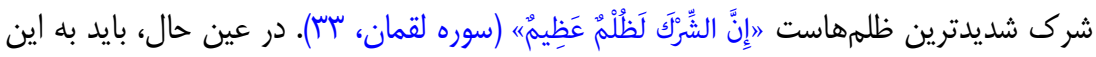
موضوع توجه داشت كه آيين اسلام بر اساس فطرت انسانها بنيان يافته است و با فطرت إنسان انسانها

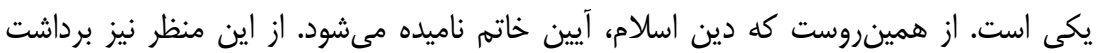
اسلامى از عدالت به عموم تعلق دارد، كويى در عالم واقع و بنا به دلايل مختلف، تلقى ها التها داز دين و

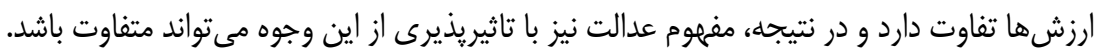

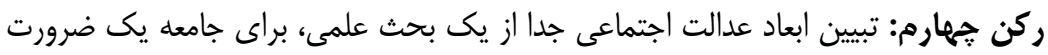

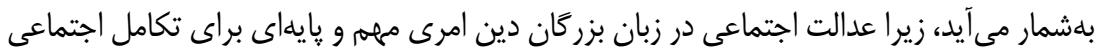

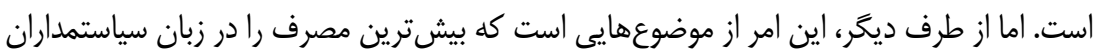

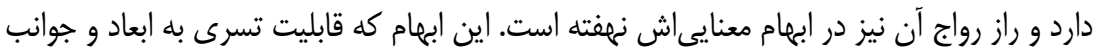

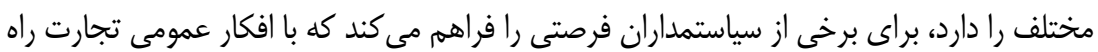

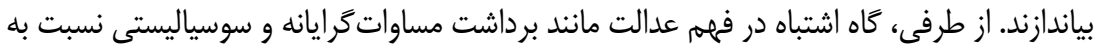

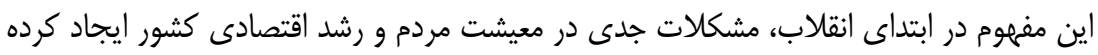

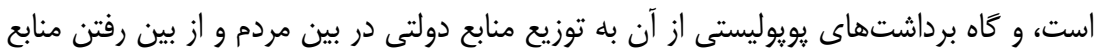

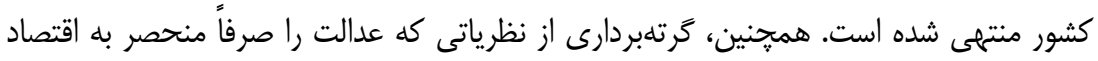


بازار آزاد و دولت حداقلى مىدانند و تجلى آن را در تغييرهاى ضريب جينى و كمكهاى اقتصادى به طبقات فرودست دنبال مى كنند، يِيامدهاى سوء دارد.

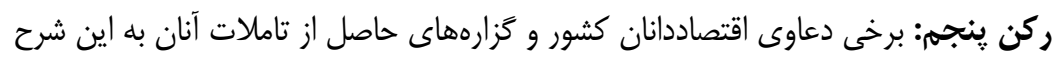

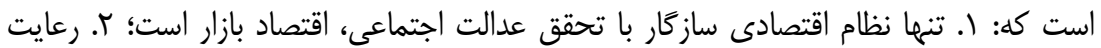

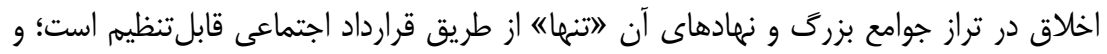

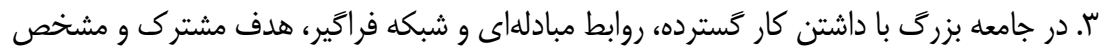

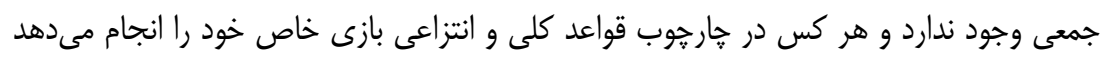

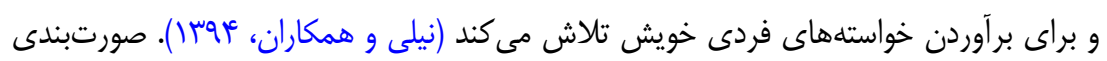

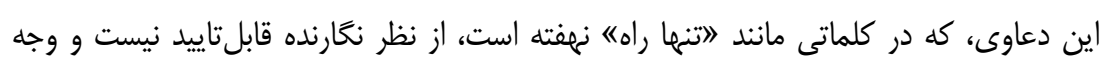

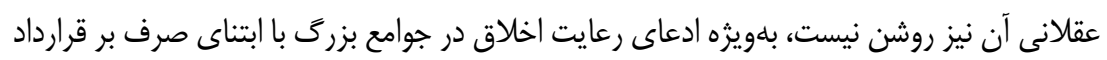

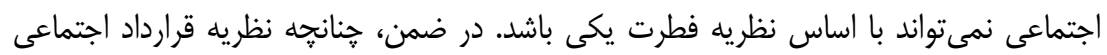

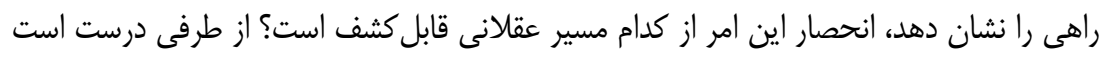

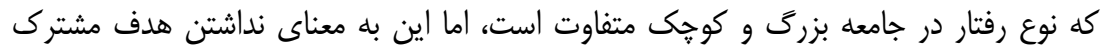

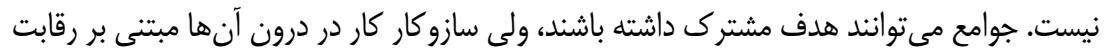

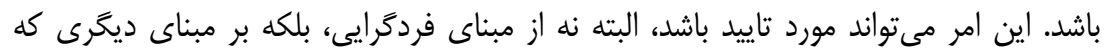

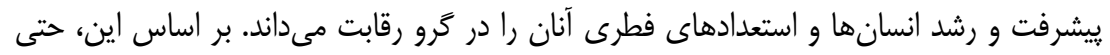

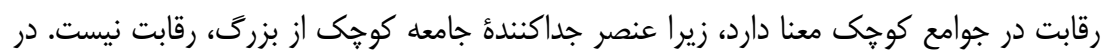

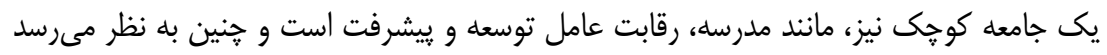

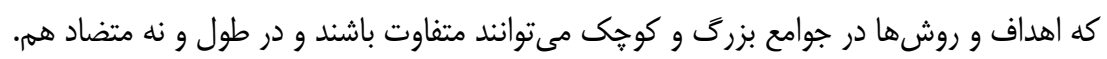
عدالت از منظر رالز، بخش ذاتى يك نظام اجتماعى است و به منزله تقواى نظام اجتماعى

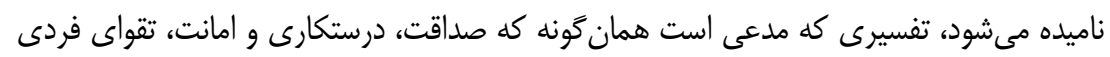

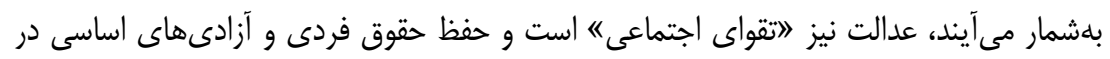

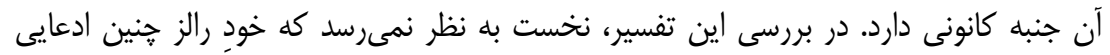

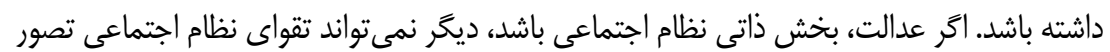

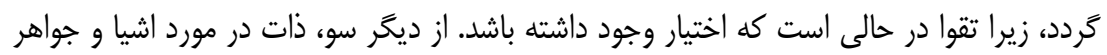

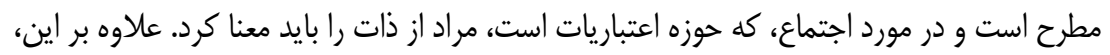

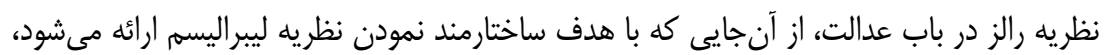

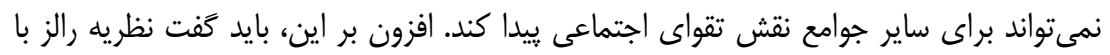


همه مولفههاى ارزشمندى كه در بر دارد، با نقدهايى جدى مواجه است، نقدهايى كه نظريه عدالت

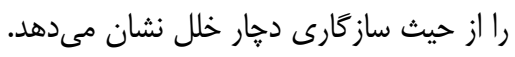

\section{بحث و نتيجه كيرى}

در اين يزوهش نشان مىدهيم كه عدالت در اسلام همهجانبه است و نهتنها تنافر و تنافى با

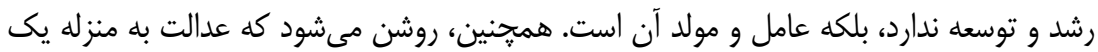

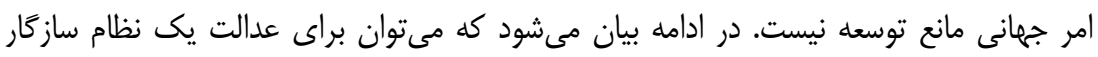

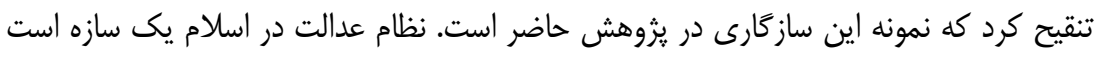

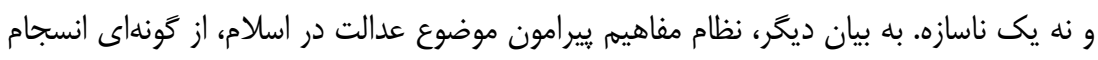

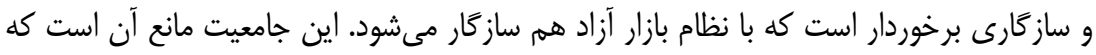

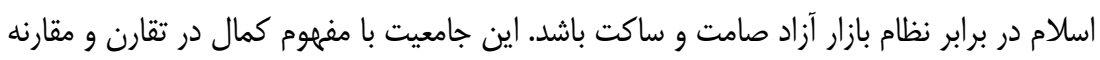

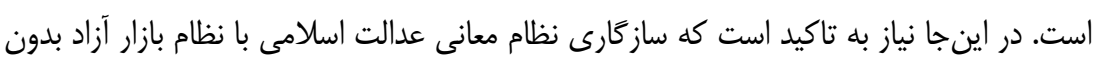

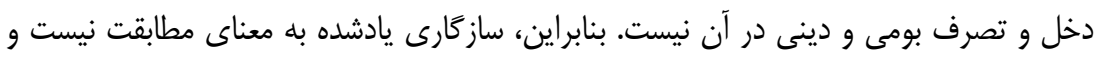

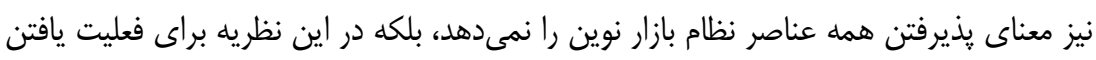

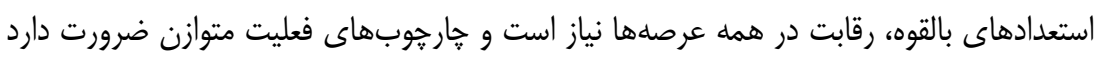

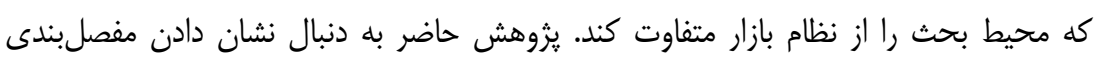

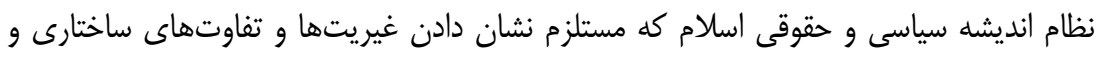

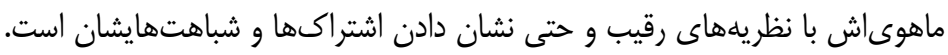

\section{منابع}

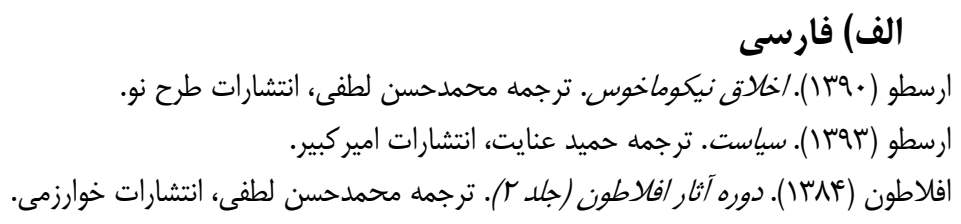

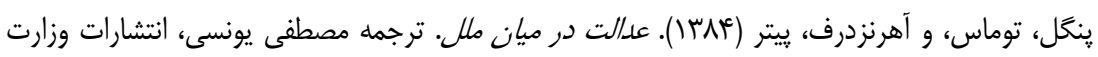

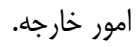

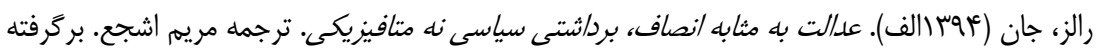

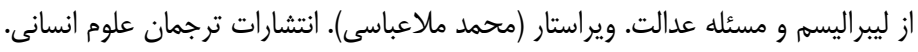


رالز، جان (أوباب). عدالت به مثابه انصاف: يكى بازكويى. ترجمه عرفان ثابتى، انتشارات ققنوس.

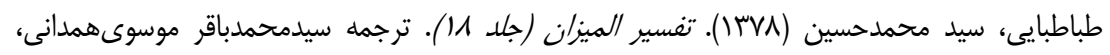

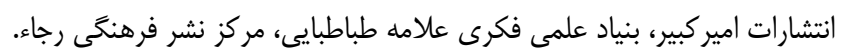

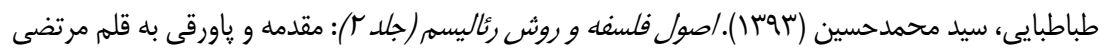
مطهرى. انتشارات صدرا.

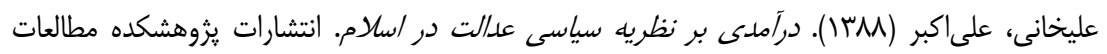

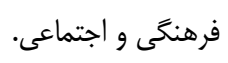

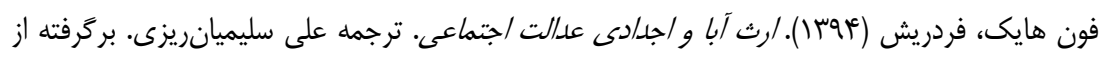

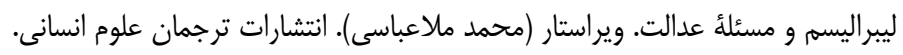

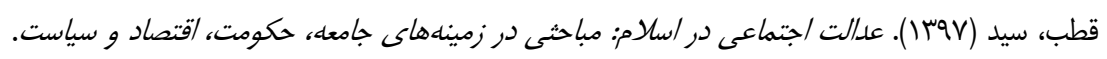

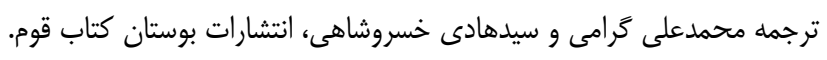

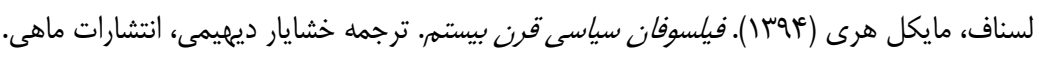

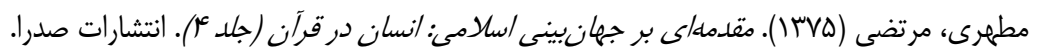

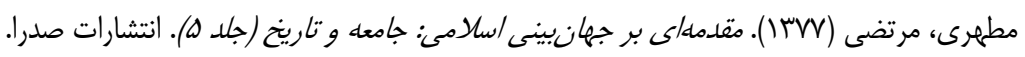

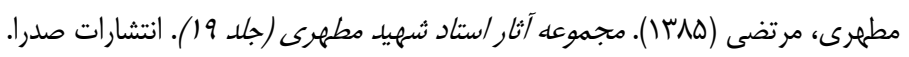

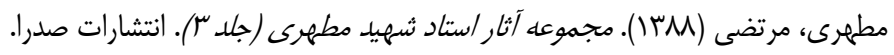

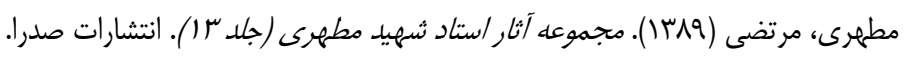

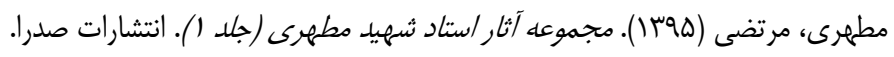

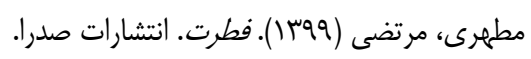

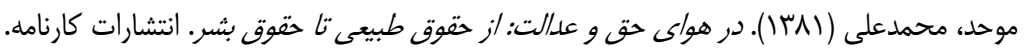

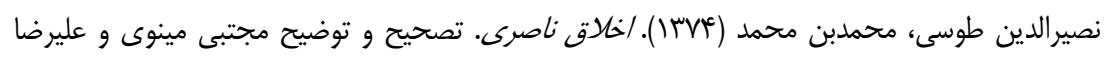
حيدرى، انتشارات خوارزمى.

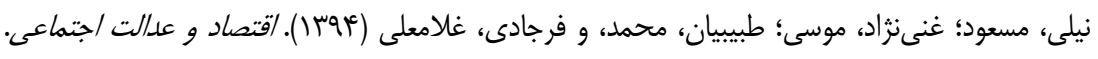

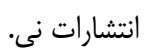

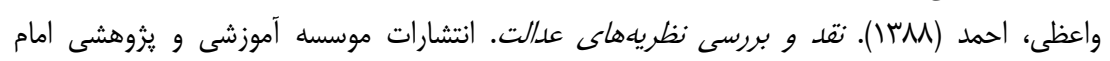

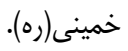

Hayek, F. A. (2012). Law, Legislation and Liberty: The Mirage of Social Justice (Vol. 2): University of Chicago Press.

Hume, D. (2003). A Treatise of Human Nature: Courier Corporation.

Locke, J. (1967). Locke: Two Treatises of Government: Cambridge University Press.

Nozick, R. (1974). Anarchy, State, and Utopia (Vol. 5038): New York: Basic 
Books.

Popper, K. R. (2020). The Open Society and Its Enemies: Princeton University Press.

Rawls, J. (2005). Political Liberalism: Columbia University Press.

Rawls, J. (2009). A Theory of Justice: Harvard University Press.

Sandel, M. J., \& Anne, T. (1998). Liberalism and the Limits of Justice: Cambridge University Press.

Sen, A. (2001). Development as Freedom: Oxford Paperbacks.

Taylor, C. (1989). Sources of the Self: Harvard University Press.

Walzer, M. (2008). Spheres of Justice: A Defense of Pluralism and Equality: Basic Books. 